\title{
Some Remarks about the Influences of Astronomical Phenomena on Islamic Architecture "Analytical and Applied Study on Selected Religious Architectural Models in Cairo"
}

\author{
Ghadeer Dardier Afify Khalifa* \\ Islamic Department, Faculty of Archaeology, Fayoum University, Egypt
}

*Corresponding author: Ghadeer Dardier Afify Khalifa, Associate Professor, Islamic Department, Faculty of Archaeology, Fayoum University, Egypt

\begin{abstract}
In researching for areas of Islamic architecture and Heritage structures, it can be noticed that they included numbers of scientific applied manifestations and astronomical phenomena. One of these architectural manifestations is the astronomical phenomena that have not been discussed deeply and have not been concentrated and strongly investigated by researchers . This study seeks to discuss the extent of effect of astronomical phenomena on Islamic architecture that include a vast layout of architectural styles and structural designs which were varied from one structure to other building through the different Islamic ages. The main Islamic architectural models include religious, funeral, civil, urban and military architectures such as Mosques, Mausoleums, Khanqahs, Zawiyas, Madrassas, Palaces, Turrets or Towers, Castles and Fortresses, in addition to domestic architecture that includes the public baths or the so-called Hammams, Fountains, Sabils and Kuttabs. For all these architectural models and structural designs of buildings, the Islamic and Heritage styles of architecture created and developed precious astronomical techniques, which were necessary to construct these architectures. But due to the wide content of the idea of this study, the topic will be limited on the influences of astronomical phenomena on Islamic architecture, analytical and applied study on selected religious architectural models in Cairo. The methodology of this study will be addressed through analytical study of the notable aspects of the extent of effect of astronomical phenomena on some selected religious architectural models in Cairo, this will be through an analytical study and discussion on the manifestations of astronomical phenomena that have been used in Islamic architecture through hypothetical issues and theoretical opinions, revolving around this case of astronomical phenomena emerged and prevailed in these architectural Islamic buildings.
\end{abstract}

Keywords: Influences; Astronomy; Astrology; Astronomers; Astronomical Phenomena; Celestial Objects; Islamic Architecture; Cairo

\section{Introduction}

Many questions arose when studying the influences of astronomical phenomena on Islamic architecture and Heritage structures, these questions can be represented as follows; Who are the astronomers and their scientific contributions? Who are the most famous scientists in the field of astronomy during the Islamic ages, and how Islamic architecture benefited from the contributions of astronomers in the Islamic ages? How was the benefit of astronomy and what are the features of Islamic astronomy and associated? Are there truly astronomical influences on Islamic architecture? What are the astronomical influences that have affected on Islamic architecture and how was the utilization of celestial objects and whether they were applied scientifically? These questions need to be addressed when referencing to the sources of Islamic architecture. In spite of the fact that the Islamic architecture has been excessively studied, discussed and investigated, it is still neglected in the views of the scientific applied studies of astronomical aspects and astrological theories that have been strongly involved in the architectural Islamic structures and Heritage buildings. It should be noted that there are 
important key references that discuss the history, methodology and developments in Islamic architecture; however, they neglect the influence of scientific issues, astronomical theories and astrological phenomena in the Islamic architecture. One of early important key references has been issued in 1913 [1] about the history of architectural development; however, it neglects the area and issue of the influence of astronomical phenomena on Islamic architecture and Heritage structures. Another major reference was issued in 1958 [2] about the account of early Islamic architecture, but it also did not discuss the issue of astronomical phenomena, in addition to what was issued in 1961 [3] on the history of architecture; on the comparative method, as well as what was published in 1994 [4] on the history of world architecture. There are also many early and recent studies [5-13] (a), but they also have not been clearly investigated on the subject and issue of the current study. It should be noted that there are prominent Muslim astronomers, who are the pioneers of astronomy throughout Islamic times, all of them have been tried to observe, monitor and control the positions of celestial objects such as stars, sun and moon; however, there is no focused study on the contributions the field of astronomy and astronomical phenomena and the extent of their relevance and effect on Islamic architecture and Heritage structures, and also how astronomy was used, as well as how to take advantage of astronomical phenomena in Islamic architecture and heritage structures. This study will focus on some remarks on the influences of astronomical phenomena on some selected religious architectural models in Cairo; it will also highlight the contributions of the most important scientists in the field of astronomy, or the so-called pioneers of astronomy through Islamic ages. The objectives of this study will be revealed through discussion, investigation, analysis that can be detected through detailed interrogation of the objects, elements and structure of the content of this study, particularly as a basis for explaining the content and significance through the discussion and interpretation. All of this will be clear through the methodology, structure and content of this study.

\section{The Methodology, Structure and Questions for Discussion}

It is worth mentioning that the methodology and structure of this study will be evident through the investigations, answers and explanations of the questions that are for discussion, these questions can be represented as follows;

\section{Who are the astronomers and their scientific contribu- tions?}

It should be noted that the astronomy is one of the oldest and important natural sciences, as well as it is from important sciences in which the astronomer cannot do and practice the experiments and tests in a direct way, these experiments are scientific procedures undertaken to make a detection or discovery, and this in order to investigate and check a hypothesis, as well as to prove a cosmic fact. Astronomer is a person who has expert knowledge of one or more of the natural or physical sciences, and in the case of this study, he is a person has expert knowledge of astronomy and astronomical phenomena, who is called a scientist in the fields of astronomy and what are related to this science [14-21]. Astronomers who are focused their field of studies on a specific scope outside the rang of the Earth, where they observe, monitor and control the astronomical objects, which represent in sun, moons, constellations, stars, planets, as well as comets and galaxies, where they use the observation and analysis for the observational data, this is beside the field of theoretical astronomy, or the so-called theoretical astronomers. They also studied the fields of astronomy, which known as planetary science, solar astronomy and physical cosmology, as well as the ancestry or origin and development or evolution of stars and orbits, in addition to the emergence and formation of comets and galaxies [22-31]. The Muslim astronomers have many contributions, where they were aware of astronomical phenomena and studied the astronomical models of stars and planets in the Ptolemaic period, also improved and developed the techniques of mathematical calculation and computation ways, in addition to improve the methods of observation, as well as creating precious observational tools, they also founded extensive observatories, in addition to improvement of planetary models in order to observe, monitor and control movement and shifts of constellations, stars and planets in accordance with the evolution of cosmology [22, 32-38].It is worth mentioning that the contributions of Muslim astronomers arrived its highest point during the so-called Islamic Golden Age (during the 8th -13th centuries), where the Islamic world was seen as a scientific center of innovations and discoveries, as well as inventions. The contributions of Muslim astronomers were extended over a wide area of the Arab lands, where the names of these Muslim scientists became known for their valuable astronomical observations and scientific calculations, which were the main cause for the emergence of the light of astronomy during the modern times. It is worth mentioning that throughout more than 1400-year of history, a large number of Muslim astronomers did pioneering works, created valuable inventions, where they participated, provided and contributed to various fields of science in general, and astronomy in particular [33, 39-44].

\section{Who are the most famous scientists in the field of as- tronomy during the Islamic ages, and how Islamic archi- tecture benefited from the contributions of astronomers in the Islamic ages?}

There are prominent Muslim astronomers, who are the pioneers of astronomy throughout Islamic times, where there are many important astronomers, but to mention not exclusively, for example Al-Khwarizmi [45-50](b), the full name is Muhammad ibn Musa alKhwarizmi (ca. 780-850), he was born in the oasis of Khwarazm in Central Asia, between Turkmenistan and Uzbekistan. Al-Khwarizmi was an astronomer, mathematician, and geographer, who was the originator of Algebra science, where the name of Algebra was derived from the book of al-Khwarizmi, known as Al-Jabr wa-al- 
Muqabalah, and he was the innovator of the so-called 'algorithm', which is a spelling transformation of a figure, symbol, or group of these denoting a number, or the so-called 'numerals system'. The contributions of al-Khwarizmi were to astronomy, cartography, geography and mathematics, where he founded the basics in trigonometry through his ordinal and organized methodology of the valuable book, known as "the Compendious Book on Calculation by Completion and Balancing" [36, 51-57]. In astronomy, the Zij of al-Khwarizmi or the deviation that is the amount by which a single measurement differs from a fixed value; it is also the action of departing from an established course or accepted standard. This work includes schedules for the motions and shifts of the sun, and the moon, in addition to five planets, where this work was considered as a turning point in the field of astronomy through the Islamic ages [22,55, 58-60]. As well as that Al-Battani [61-66] (c), the full name is Abu Abd Allah Muhammad ibn Jabir ibn Sinan al-Raqqi al-Battani (ca. 858 - 929), he was born in ancient village called Harran is now in the range of Turkey; his father was also a well-known manufacturer of scientific instruments. Al-Battani was an astrologer, astronomer and mathematician, and he has many scientific contributions in the field of astronomy and astronomical phenomena [61-66]. Moreover, Al-Sufi [67-80](d), the full name is Abd al-Rahman Abu al-Husayn al-Sufi (ca. 903-986); he was born in Ray city of Iran. Al-Sufi was astronomer, where he dedicated his life on translating astronomical studies of the Greeks, such as the great work called Almagest of Ptolemy, where he contributed various rectifications to the list of stars and constellations of Ptolemy, such as the estimated brightness and extents that often swerved from what were existed in Ptolemy work of Almagest. Al-Sufi was one of Muslims astronomers to try to link the traditional names of Arabic stars with those constellations of the Greeks [81-93].There is also Ibn Yunus [94-96] (e), the full name is Abu al-Hasan Ali ibn Abd al-Rahman ibn Ahmad ibn Yunus al-Sadafi Al-Misri, (ca.950-1009); he was born in Al Fustat of Egypt. Ibn Yunus dedicated his life in Astrology, Astronomy and used the Pendulum in measuring time, where he was one of the most important Egyptians astronomers and mathematician; his scientific works were based on precise calculations and accurate measurments according to scientific details [97-102]. Furthermore, Al-Biruni[103-108] (f), the full name is Abu Rayhan Muhammad ibn Ahmad Al-Biruni (ca. 973- 1050); he was born in city of Kath of the large oasis called Khwarazm, now known as Uzbekistan in Central Asia. Al-Biruni devoted his life to astronomy, astrology, Physics, Pharmacology Mineralogy, mathematics, and related matters such as mathematical geography, where he was one of the most important scientists in Islamic times; this is because of his scientific works, discoveries and scientific methodology [109-114]. Moreover, Omar Al-Khayyam [115-118], the full name is Ghiyath Al-Din Abu el-Fath Umar ibn Ibrahim AlNisaburi Al-Khayyami (ca.1048-1131); he was born in the city of Nishapur in the range of province of Khorasan in the northeast of
Iran. Omar Al-Khayyam devoted his life to astronomy, astrology and Mathematics, where he addressed some classifications for the equations of cubics, and geometrical solutions to intersection or crossing of conic forms, in addition to his valuable work is called"a commentary on the difficulties concerning the postulates of Euclid's Elements". With regard to astronomy, he contributed to extensive astronomical observations, as well as modified the astronomical schedules, and also devised the so-called 'Jalali calendar', which was a precious solar calendar and was more precious than the Julian calendar devised by Julius Caesar (ca. 46 BC), where it was a repair of the Roman calendar, in which there is one day represents a fault, which has accumulated and increased over the years, as well as it was approached and comparable to the Gregorian calendar of 1582 [119-127].

\section{How was the benefit of astronomy and what are the fea- tures of Islamic astronomy and associated?}

During the $8^{\text {th }}-15^{\text {th }}$ centuries, there were some benefits of astronomy and astronomers, which were carried through precious observations and exact monitoring of cosmic phenomena and celestial objects, resulting in valuable astronomical tables that benefit Islamic architecture. Later, the Islamic astronomy has a great impact on other astronomical features that prevailed in other countries across the world such as the astronomy of Byzantine Empire, Indian astronomy, Chinese and European astronomy, where there are a great number of names of stars and constellations are still known by their Arabic names [128-130]. The Muslim scientists and astronomers studied and exceeded in many fields of scientific knowledge in general, and in astronomy in particular, this was almost from the $8^{\text {th }}-15^{\text {th }}$ centuries, where there were nearly ten thousands manuscripts related to Islamic astronomical phenomena and approximately more than a thousand tools linked to astronomical phenomena during the Islamic ages, which are kept in museums and libraries of Near, Middle and Far East, as well as in different counties around the world [36, 131136]. It is worth mentioning that the most important features of Islamic astronomy and what related to astronomical phenomena are the models of astronomical tools [137-140] and how to apply astronomical techniques in different fields of religious beliefs and rituals during the different Islamic ages. Moreover, the Islamic calendar, or the so-called Islamic lunar calendar that depends on the phases of the moon, and from an astronomical point of view, it relates to the times of prayer, as well as the direction of Qiblah, where it must be oriented towards the direction of the Sacred Mosque of Kaaba at Mecca, in addition to the only important architectural requirement in any mosque is to correctly directed towards the Qiblah of Kaaba. It is worth mentioning that the locating, monitoring, directing and determining for the true direction of the Qiblah was an important matter and critical issue of the Islamic architectural scientific studies and for Muslim astronomers during the Islamic Ages [141-146]. There are some links and requirments 
associated with the manifestations of Islamic astronomy, which can be addressed through the astronomical phenomena that require survey and surveyor, geography and geographer, mathematics and mathematician, in addition to scientific observations of astronomical phenomena related to astronomy and astronomer, as well as astrology and astrologer [24, 147-154]. Furthermore, there are scientific studies conducted by Muslim astronomers throughout the Islamic ages and related to orientation schedules of the Qiblah $[138,155-163]$. It should be noted that there linked studies to the field of astronomy and astronomical phenomena, known as Geodetic measurements that are related to geodesy, particularly as applied to land surveying and what are linked to celestial objects [164-166]. The science of Al-Miqat or the so-called "ilm al-miqat" that is linked to the astronomy and astronomical phenomena during Islamic ages, where Muslim astronomers produced a technique linked to astronomical phenomena, which was based on a well-known science of astronomical time-keeping, known as 'ilm al-miqat, which is also called 'ilm al-mawaqit [145,146, 167,168]. It can be said that the mosques and madrasas in Cairo, which were from early Mamluk age upwards used astronomical tables related with astronomical phenomena, this was in order to determine time by the sun and to regulate the five daily prayers times, which linked to the science of timing or the so-called muwaqit $[145,146$, 167-169]. Some of these astronomical tables were collected by the Fatimid astronomer called Ibn Yunus, and other astronomical tables were gathered by different Mamluk astronomers. One of these tables regulates the altitude or the rise of the sun in points or degrees and minutes that agree almost exactly to each day of the solar year [169-171] (Figure 1).

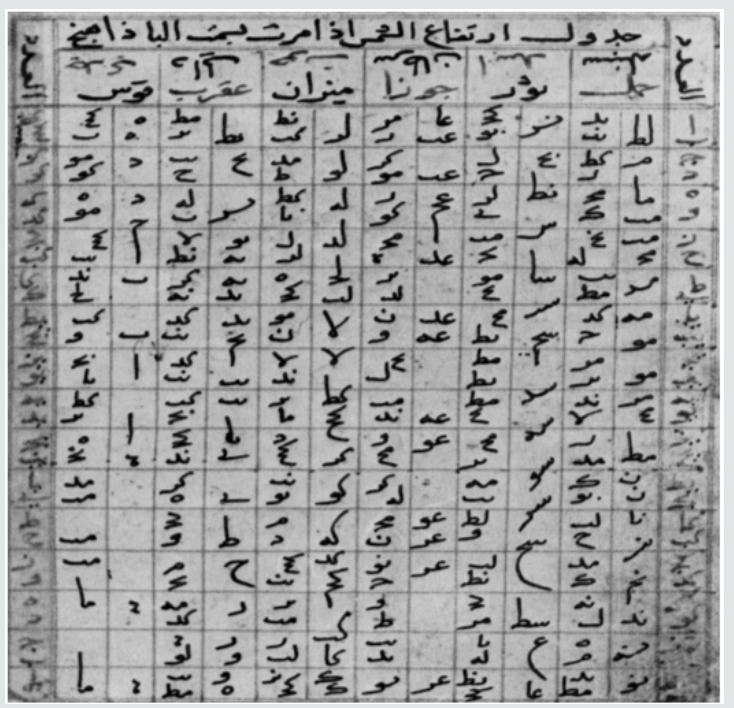

Figure 1: One of the astronomical tables which used in Cairo to regulate the altitude or the rise of the sun.

\section{Are there truly astronomical influences on Islamic architecture?}

There are many astronomical influences [172] that are closely linked to Islamic architecture, which was resulted from the idea and through the process of linking the architectural structures of the earth with the celestial objects. The influences are emerged through the ideas and concepts of linking between the designs of architecture and some astronomical phenomena that are related to the apparent movement of the sun and the moon in particular, or some other constellations and planets that could not be seen with the naked eye. The astronomical phenomena were used by Muslim astronomers in monitoring and directing the Qiblah of mosques to Mecca, as well as these astronomical phenomena were influential factors in determining prayer times, for this purpose, the astronomers used an effective method called sundials [173$175](\mathrm{g})$, which were particularly used in determing prayer times of Dhuhr (midday) and 'Asr (afternoon) [176]. In Islamic religious architecture of Cairo, the sundials were used effectively, for example but not limited to the marble sundial of Al-Azhar mosque, dating back to the12th century AH [177] (Figure 2). There is also the sundial of mosque of Muhammad Bey Abu al-Dhahab that is located beside the mosque of Al-Azhar, Cairo-Egypt, dating back to 1188 AH/ 1704 AD [178-180](h)(Figure 3).

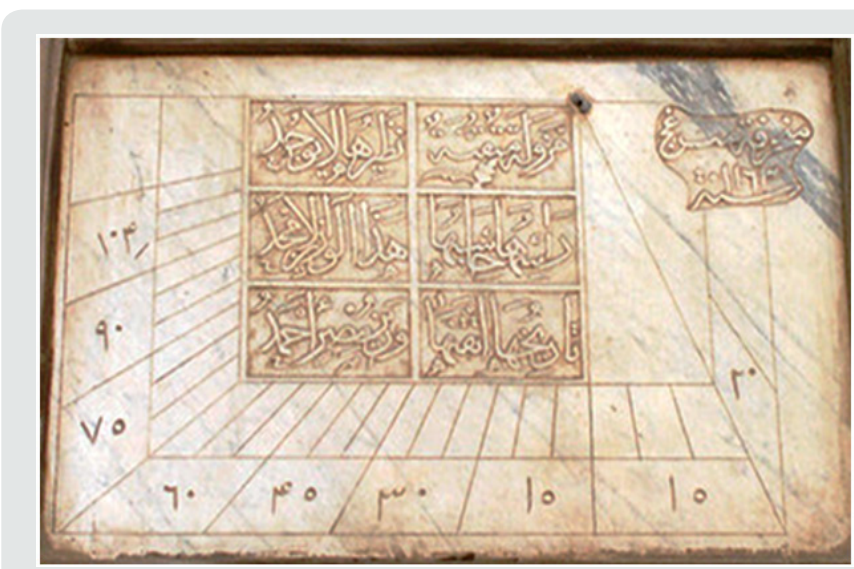

Figure 2: The sundial of Al-Azhar mosque, Cairo-Egypt (by the researcher).

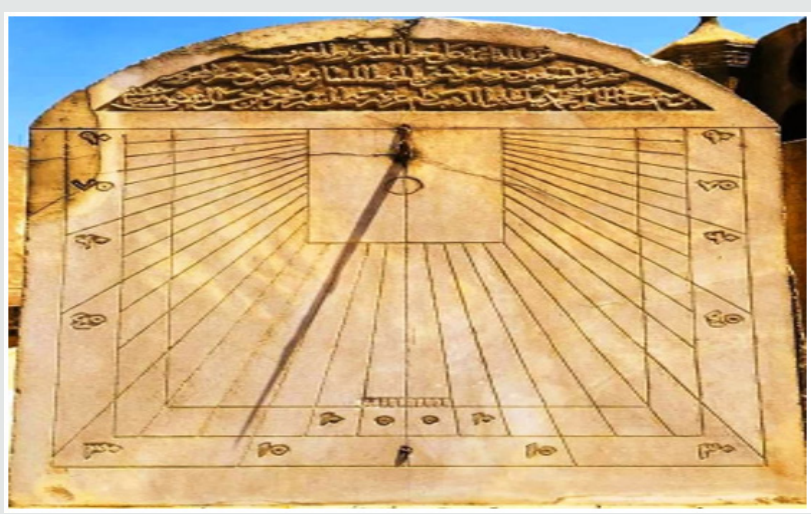

Figure 3: The sundial of mosque and of Muhammad Bey Abu al-Dhahab, Cairo-Egypt (by the researcher).

Often, the design style of Islamic architecture was in many cases associated with certain astronomical and cosmic phenomena, where it seems clear how far Muslims astronomers during 
the Islamic ages are looking for the secrets of heavens, virtual movement and the phases of celestial objects, which affected the Islamic architecture that was strongly associated with these astronomical phenomena and was greatly influenced by them, which was certainly reflected in the ways, designs and styles of architectural buildings during the Islamic ages. It should be noted that there are some functional objectives and methodological requirements needed from the observation processes of these astronomical phenomena, such as the need for a timeline schedule, calendar, or a graphic representation of the passage of time as a line, which should be consistent, accurate and balanced according to the mathematical and astronomical methods, as well as for the performance of religious rites and Islamic religious ceremonies [22, 181-191], this is necessarily linked to the process of establishing astronomical observatories to monitor and control celestial bodies, which are associated with the time calculation, or the so-called 'ilm al-miqat (science of Mawaqit) [24,192-196]. It is worth mentioning that the seventh century A.H. is one of the most important historical periods in the construction of Islamic observatories, where the construction of an observatory was built at this time in the city of Tabriz, known as the Maragha observatory that was one of the historical capitals of Iran, which was managed by many Muslim astronomers such as Nasir al-Din al-Tusi, the full name is Muhammad ibn Muhammad ibn al-Hasan al-Tusi (ca. 1201-1274) $[24,197-206]$.In the fifteenth century, Ulugh Bek, the full name is Mirza Muhammad Taraghay bin Shahrukh, he was the Timurid Sultan of the city of Samarkand in eastern Uzbekistan, he also was a mathematician and astronomer, where he devoted his life to astronomy and astronomical phenomena, as well as he produced some astronomical schedules [207-210] and constructed a more technical and advanced observatory in Samarkand. In 1908, the archaeological scientist Vassily Lavrentyevich Vyatkin succeeded in finding an endowment of the construction endowments, which was identified its exact location and was able, through his archaeological excavations, to find remains of a large arch that was used to determine the midday time [76, 95, 211-214]. The Mizwala or the so-called sundial [215-219] (i) and the astrolabe [220-222] (j) were astronomical measurement tools, consisted of disks with the edge marked in degrees as well as pivoted pointers, which were used as an effective methods linked to celestial objects and were used to observe, monitor and detect celestial bodies altitudes that is the height of an object or point in relation to sea level or ground level. Furthermore, these tools were used in navigation in order to calculate latitude, which is the angular distance of a place north or south of the earth's equator, or of a celestial object north or south of the celestial equator, usually expressed in degrees and minutes. Sundials and astrolabes were devices to detect and identify the time of day when sunlight is in the obvious location in the sky, these astronomical tools were found on many facades of mosques or inside the open courtyards (Sahn) of mosques in most countries of the Islamic world [223-227].

\section{What are the astronomical influences that have affected on Islamic architecture and how was the utilization of celestial objects and whether they were applied scien- tifically?}

Islamic architecture was influenced by astronomical objects, celestial bodies and cosmic phenomena, which lie in the knowledge of Muslim astronomers and architects of importance and significance of cosmic phenomena, celestial objects, astronomical manifestations that influenced the architectural characteristics of Islamic architecture, in addition to how to benefit from these phenomena in the processes of architectural construction,as well as how to take advantage of these phenomena and manifestations in structural and geometrical building designs. Examples of these astronomical phenomena lie in the use of astronomical phenomena to determine the exact and correct direction of the Qiblah $[138,156,158-159,228-229]$, also the use of sundials [230-234] and astrolabes [235-239] in mosques to adjust prayer times[240-242], as well as tracking and monitoring the movement of celestial objects in their cosmic cycles and astronomical phases [243-244], in addition to observing, tracking and monitoring the motion of the sun, as well as the orbits and phases of the moon [22,129, 145-146, $183-185,187,192,245]$, this in order to be used in the process of timekeeping [145-146] and to be benefited from them in adjusting prayer times [167], where there is a need for determiningand adjusting the time of certain acts of worship in Islamic beliefs[246], such as prayer times associated with the movement of the sun, as well the length of shadows that were differentiated. It should be noted that some acts of worship in Islamic beliefs such as fasting or Sawm, Hajj, and Zakat (Zakah) [247-248] which were associated with monitoring the crescent, or the so-called crescent observation and also linked to determining the beginnings and ends of Arab months [249-254]. It is worth mentioning that during 15th century, it is believed that Samarkand was known as the astronomical capital of the world, where by the observations of astronomers in observatory of Samarkand and through the astronomical tables, it was clear that the planet of Saturn, the sixth planet from the sun in the solar system, takes about 29 years amongst the constellations and stars to come back to the same location, this was its revolution period, a period of 29 years around the Sun, and this was the expected length period of Saturn revolution as described by the astronomers and astronomical tables in the observatory of Samarkand [255-257]. From the above, it is clear that the Islamic astronomy was applied scientifically and practically, which led to be influential in astronomy in most countries of the world.

\section{Analytical and Applied study of the Influences of Astronomical Phenomena on Islamic Architecture}

There are many Islamic architectural models that have been closely associated with astronomical phenomena, and here will address the most important architectural models as follows; 


\section{The primary Mosques in Islamic times and the process of directing towards the Qiblah}

The first mosques were established in Islamic times depending on some cosmic and astronomical phenomena such as the sun, moon, stars and winds, which were the most practical methods to find thedirection of the Qiblah. These astronomical phenomena were also used to determine and adjust the calendar, whether it be solar, lunar, astral, agricultural and religious, as well as these phenomena used in reckoning the times of day and night-time, this was by the length of the shadow, in addition to the locations, phases and passes of the moon and the sun, where from fourteen centuries ago, there were many verses in the Qur'an that describe how Allah created the cosmic and astronomical phenomena. For example, but not limited in the verse five of Surah Yunus from the Qura'n, Allah Almighty said" He is who made the sun a shining light and the moon a derived light and determined for it phases that you may know the number of years and account [of time]"[258-260](k). It is worth mentioning that the Qiblah has been adjusted and determined according to the astronomical horizon of the required phenomenon such as the rise or down of a notable star, as well as the locations of the sun at the equal point of night and day or the so-called equinoxes, in which the center of the seen sun is directly above the equator, in addition to the summer and winter solstices or the socalled solstices, in which either of the two times, known as summer solstice and the winter solstice of the year, this when the sun reaches its highest or lowest point in the sky at noon, marked by the longest and shortest days [261-265]. For example, it is known that the stars are raised and dropped at specific ranges on the horizon for a certain location, where at the time of the equinoxes, the rise and set of the sun determine the east and west, and the locations of the sunrise and sunset at the solstices will be about 30 degrees in a northward position or direction in middle of the summer, and about 30 degrees in a southward position or direction in middle of the winter.In North West Africa, the Qiblah will be towards the sunrise at the time of the equinoxes; in Egypt, the Qiblah will be towards the sunrise at the time of the middle of the winter; in Syria, the Qiblah will be towards the rise of the star known as Canopus; in Iraq, the Qiblah will be towards the sunset at the time of the middle of the winter; in India, the Qiblah will be towards the sunset at the time of the equinoxes; in Yemen, the Qiblah will be in the direction of the northern wind blowing, which will be towards the polar star that does not rise nor fall, however its location in the north [138, 266-268] (Figures 4-5).

mosques, as well as the design of Islamic structures and cities, which were associated with the detection and control in the direction of the Qiblah. It is worth mentioning that some of the first mosques were directed towards the sunrise in winter time, this is due to the belief that makes the walls of the Qiblah are paralleled into the northwest wall of the Kaa'ba, and this applies to some of the oldest mosques established in Egypt like the mosque of Amr ibn al-'as in Fustat. However, the major mosque should face the vertical direction of sunrise in summer time, where the same direction was identical to the northwestern wall of the Kaa'ba [158, 269]. The direction of qiblah and the orientation of the first mosque built in Al Fustat, Cairo- Egypt, which oriented to the sunrise in the winter season, where this mosque was constructed in the winter season of the year 641-642, so the qiblah was in the direction of sunrise in the winter at about 27 degrees southeast [169] (Figures 4-5).

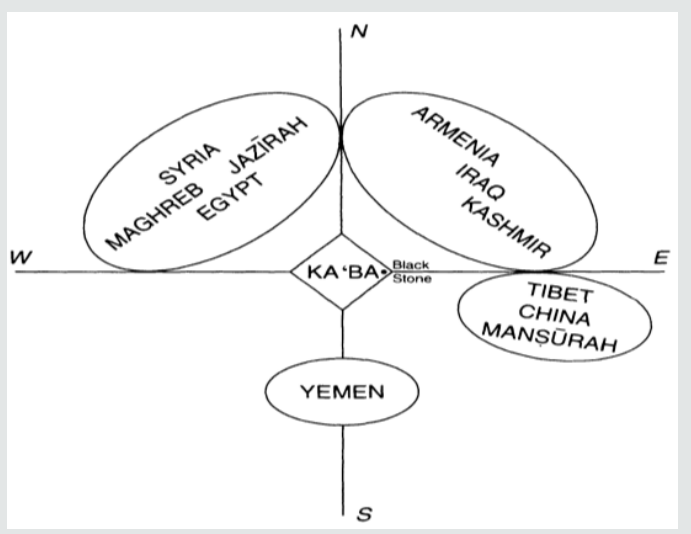

Figure 4: A diagram illustrates how astronomical directions were determined by Ibn Khordadbeh, the $9^{\text {th }}$ century .

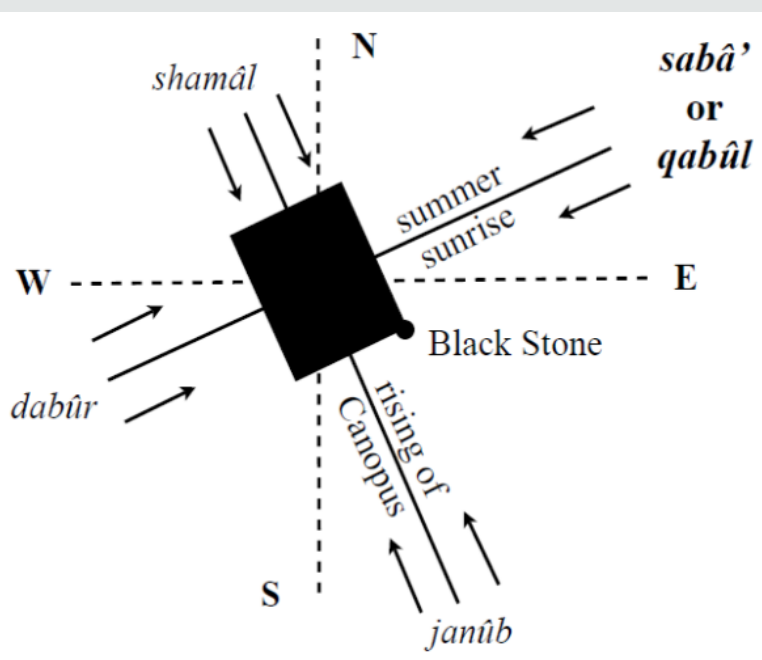

Figure 5: A diagram explains the cardinal winds, including the Qabūl wind or the so-called Sabā, as well as the dabûr wind and the astronomical objects such as Canopus that is from the most brightest star in the sky and in the southern hemisphere, as well as the process of Canopus rising in a vertical way to the axis through the sunrise in the summer and sunset in the winter in accordance to the latitude of Mecca (After: King, D., (2018). Finding the qibla by the sun and stars, a survey of the sources of Islamic sacred geography, Johann Wolfgang Goethe University, Frankfurt, p.8).

\section{The Kaa'ba and its relation to astronomical phenomena}

The Kaaba, the most sacred place in Islam, is located in Makkah in western Saudi Arabia, which means a cube in Arabic; it is a 
square stone building, draped in a veil of silk and cotton, where Muslims must face during prayer times. Noteworthy that the axis of the Kaa'ba is oriented towards the real north, with a deviation of about 7 degrees to the east, the process of directing the Kaa'ba in this technique made it related to some astronomical phenomena, where the sun rises in the summer in front of the northern wall, which by the eastern door of the Kaa'ba, and in winter, the sun goes down in front of the north-west wall, between the Yamani and Shami corners, moreover the perpendicular direction to the rib between the corner of the Black Stone and the Yamani corner takes the direction of sunrise in winter, and at the same time, it takes the direction of the star Suhail, or the so-called Suhail of Yemen at sunrise to the south east. The rib between the Iraqi corner and the Shami corner takes the direction of three stars in the hands of the plough in the Big Dipper group, which called Banat Na'sh by the Arabs, consisting of seven bright stars of the constellation Ursa Major [143,270-271]. It is clear that the influences of astronomical phenomena including constellations and stars such as Canopus, known as Suhayl, along with the azimuth of sunrise and sunset, and the azimuth for the star Canopus were affected on the Kaa'ba and on the sacred geography of Makkah (Figures 6-7).

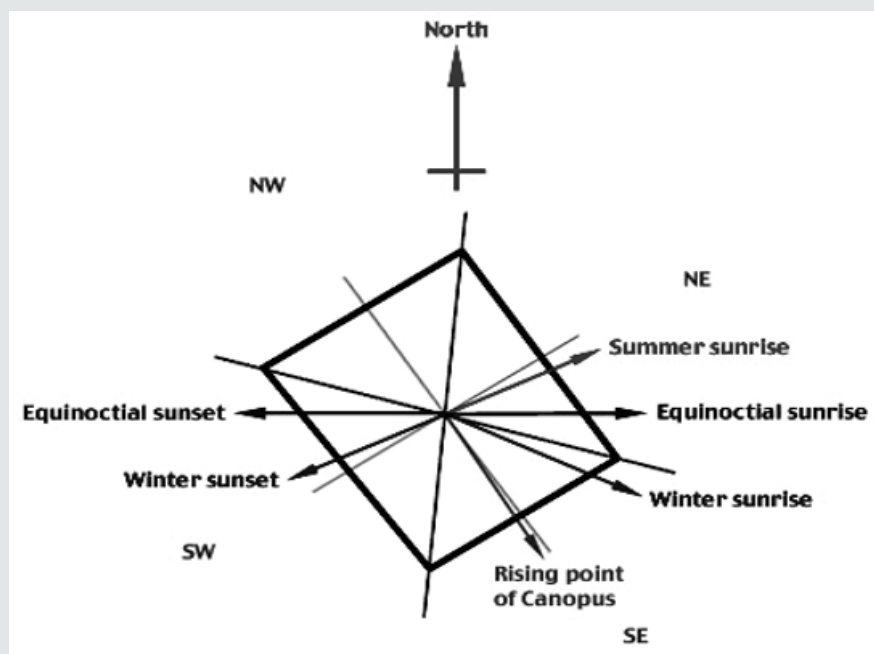

Figure 6: Astronomical orientations and alignments of the Kaa'ba, including sacred geography and topography of Makkah and related methods of directing towards the Kaa'ba according to the azimuth of sunrise and sunset, and the azimuth for the star Canopus.

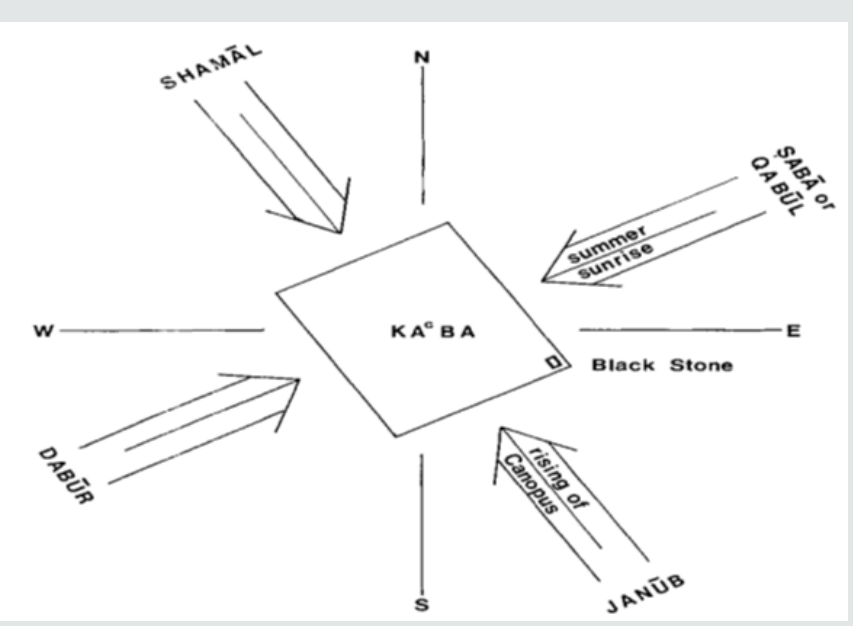

Figure 7: A design of the Kaa'ba and the alignments of its axes with the four directions of the cardinal winds, and this were described in the Arabic and Islamic sources, dating back to the $7^{\text {th }}$ century.

After $623 \mathrm{AD} /$ Second year $\mathrm{AH}$, the direction of these prayers was towards the Kaaba of Makkah instead of Jerusalem; this is right direction and sacred direction to pray, known as the Qiblah [152,272-279]. The Qiblah was determined by Muslim astronomers through the direction of the major circle that link the locality to
Makkah, which has been measured by the angle of the regional meridian that is known as a circle of constant longitude that pass through a given location on the earth's surface and the terrestrial poles [266,275,278] (Figure 8). 


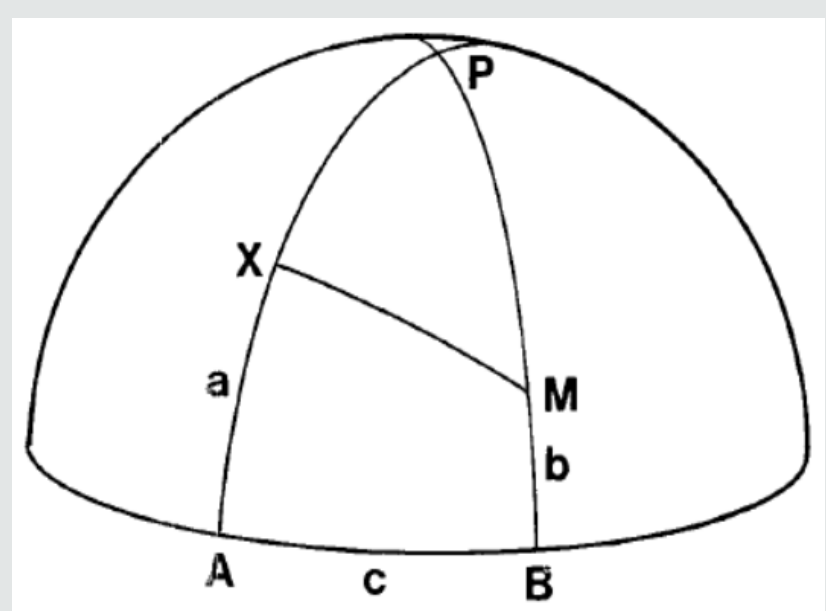

Figure 8: The mathematical issue of finding and determining the Makkah direction of $(M)$ from a grade $(X)$ that involve detecting the angle that the great-circle arch (XM) produce with (PXA) the so-called meridian at the point of $(\mathrm{X})$, where it is needed to be known the latitudes or the angular distance of a place north or south of the earth's equator, or of a celestial object north or south of the celestial equator, commonly expressed in degrees and minutes, where the latitudes of $(X)$ and $(M)$ will be measured by $(\mathrm{XA})$ which equals (a), and also $(\mathrm{MB})$ that equals $(\mathrm{b})$, as well as $(\mathrm{AB})$ which is an arch of the equator, then the longitude difference will be measured by $(\mathrm{AB})$ which equals(c).

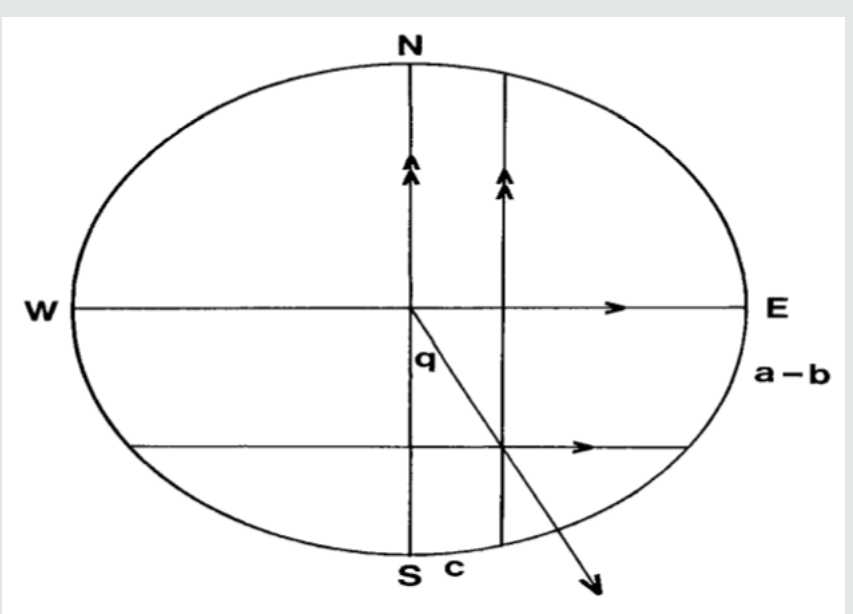

Figure 9: A geometrical diagram for detecting the Qiblah direction, including cardinal directions that are in the circle horizon, then parallel line to the east and west, where the separated line will be the latitude which measured by the circle, in addition to the drawn line between the middle point or centre of the circle and the grade of intersection, known as the crossing point, where the intersection between the last two lines will be direction of the Qiblah.

Since the eighth century onwards, there were a large number of Islamic astronomical manuscripts [280] that include tables, known as Zijes, including measurable factors used for astronomical and mathematical determination of the locations of the sun, moon, stars, constellations and planets, as well as the procedures for determining the Qiblah [22,281-282] (Figures 9-10).

From the above mentioned, there are some factors linked to the influences of astronomical phenomena on Islamic religious architecture in general, and the architecture of mosques in particular, including sacred geography and topography of Makkah and related methods of directing towards the Kaa'ba, constellations and stars such as Canopus, known as Suhayl which is the brightest star in the southern sky of Makkah, along with the summer and winter sunrise or sunset, summer and winter solstices, the cardinal directions and monsoon, and the orientation of mosques towards the qiblah and mihrab (Figures 4-11). 


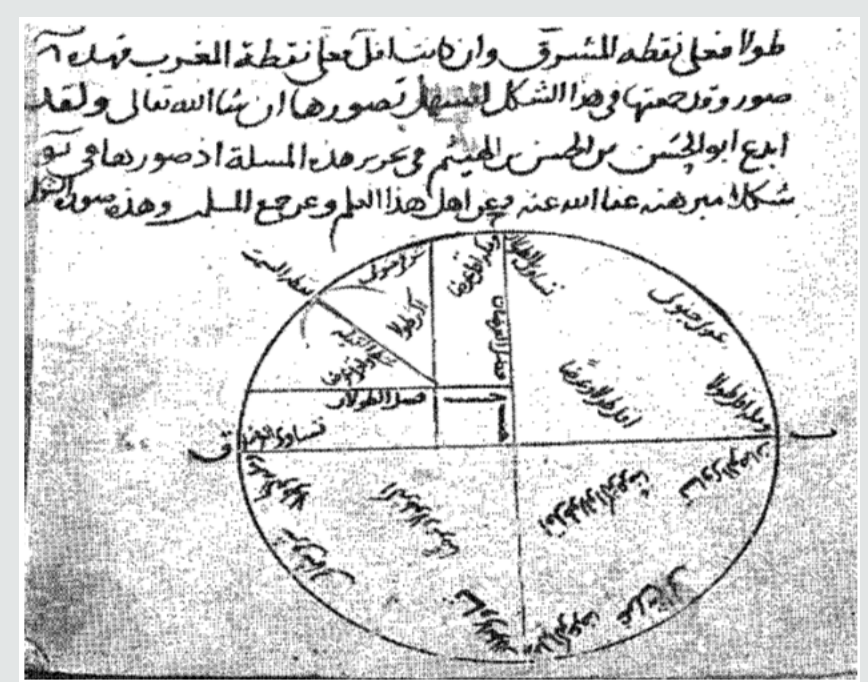

Figure 10: An illustration extract from astronomical manuscript of Ibn al-Sarraj al-Dimashqi, dating back to the $14^{\text {th }}$ century, which reveals the direction of the Qiblah.

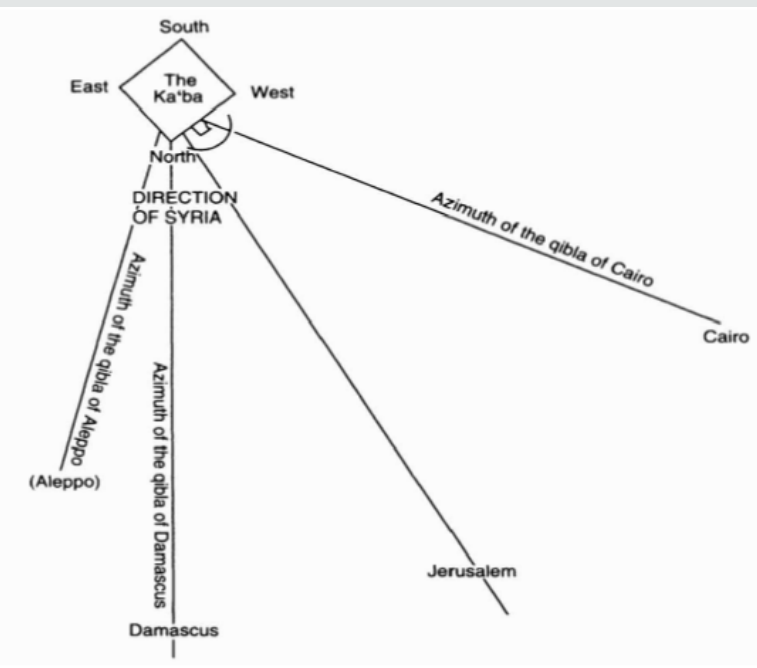

Figure 11: A diagram notifies the directions of the Kaa'ba and orientations of the qiblah according to different sites such as Cairo, Jerusalem and Damascus.

\section{Applied study on selected models of Islamic} religious architecture in Cairo

The Mosque of Amr ibn al-As in Al Fustat, which was built in 641-642 AD [283-284], the directions of the qiblah adjusted according to the channel that linking the Nile to the Red Sea, this channel was in the north of Al Fustat that was built by the ancient Egyptians and reconstructed or restored by the Muslims, so there were orthogonal streets close to the side of the channel, which was flowed in a vertical direction to the qiblah of the Mosque of Amr ibn al-As in Al Fustat. Therefore, the whole city of Al Fustat was designed around 27 degrees southeast of the qiblah. It is reported that the Fatimid astronomer known as Ibn Yunus regulated the qiblah of the Mosque of Amr ibn al-As in Al Fustat by mathematical procedures as about 37 degrees southeast [266, 285](Figure 12).

The historian and geographer called Al-Bakri [286-287](l) mentioned that when the Fatimid Caliph Al-Mu'izz [288](m) wanted to convert or change the qiblah of the mosque of Amr, almost in 956$957 \mathrm{AD}$, there was a great objection due to redirect errors that can occur $[169,289]$ (Figures 6-13). It is worth mentioning that there were several directions for the qiblah that used in the mosques of Cairo-Egypt, and when the historian called Al-Maqrizi [290](n) discussed the deviations of the mihrabs[291-292](o) in Islamic mosques in Egypt, he identified at least four different orientations for the mihrabs[169, 289](Figure 13). 


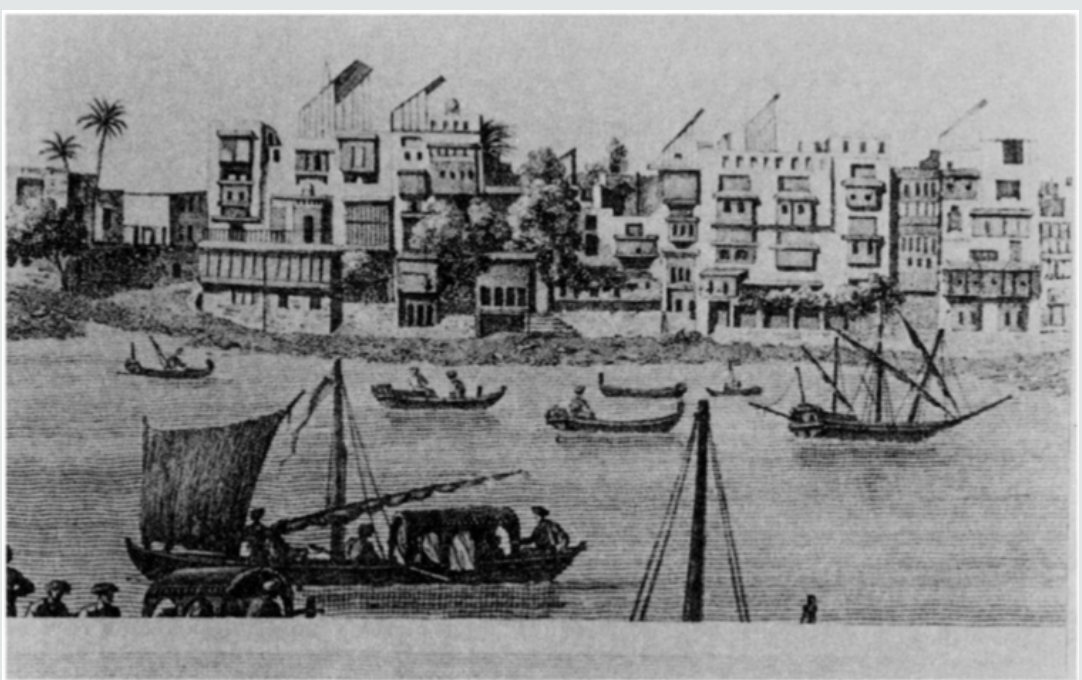

Figure 12: A scene of the Old Islamic Cairo, where the channel is illustrated.

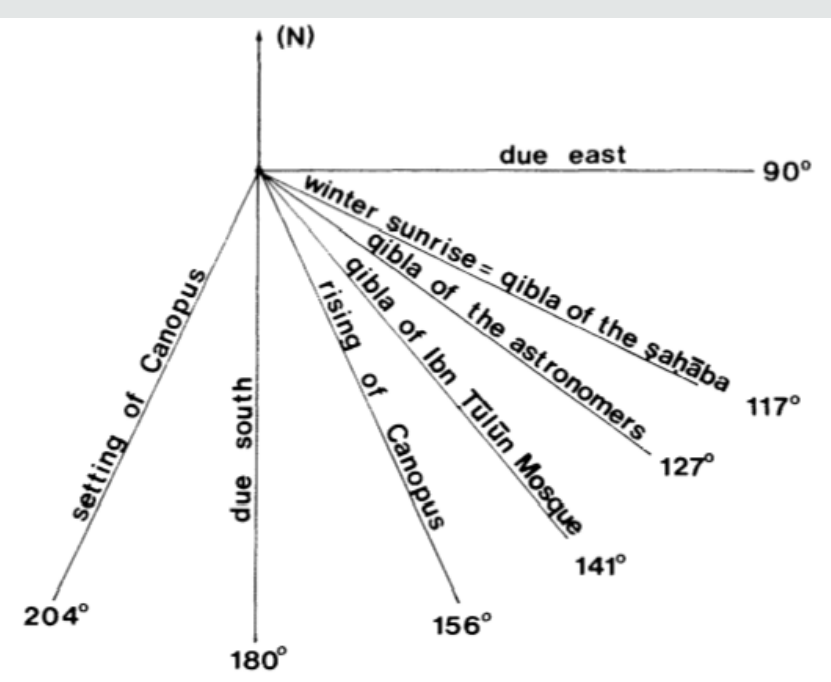

Figure 13: The different orientations for the qiblahs that was used in Islamic mosques of Egypt according to Al-Maqrizi.

In the previous diagram (Figure 13) and as Al-Mqrizi mentioned that the first direction of the qiblah was in the mosque of Amr in Al Fustat, this was according to the sunrise in winter season at about 117 degrees, which known as the qiblah of $\mathrm{Al}$ sahabah or the companions of the Prophet [293](p), while the second direction of the qiblah and orientation of the mihrab was in the mosque of Ibn Tulun[283](q) at about 141 degrees south of the qiblah of astronomers that was calculated mathematically; the third qiblah direction was in the mosque of Al Azhar that was also adjusted and calculated mathematically, and the fourth qiblah direction and orientation of the mihrab was in the city of the dead, or the so-called Al-Qarafa of Cairo [294-295](r), the main layout axis of Al-Qarafa and most of the surrounding mosques were oriented in a southwards, this is due to the astronomical phenomena accounts of the Qiblah direction, where the internal and external layouts of AlQarafa and its architectural components were roughly arranged and aligned with the astronomical direction of the Qiblah $[138,169,266]$. The first mosques of the Fatimid religious architecture in Cairo, such as the Mosque of Al-Hakim bi-Amr Allah [296-299] (s) and the Mosque of Al-Azhar [300-301] ( $\mathrm{t}$ ) were constructed at about 10 degrees inclined to the street design in order to agree with the direction of the qiblah [266]. It was noted that some Mamlūk religious architecture in Cairo are arranged in a straight line with the outside design of the Fatimid city and the internal qiblah direction of the Fatimid mosques, which was in 117 degree according to winter sunrise, and during the 10th century upwards the direction of qiblah was in 127 degree. In some districts of Cairo, the direction of the qiblah was adjusted according to the rising and setting of the star called Canopus; this was between 156 and 204 degrees [138, $266,302]$. So there are some adjustments that have occured in the direction of the qiblah and there were different directions for the qiblah and various orientations for mosques (Figure 14). 


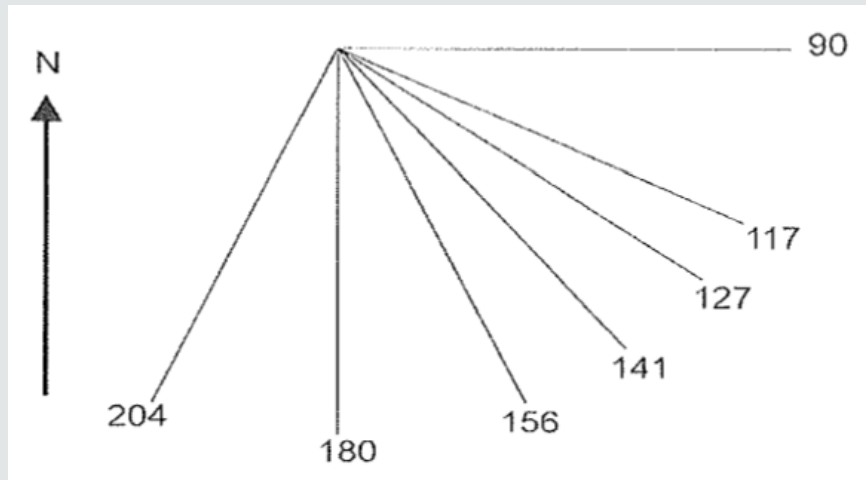

Figure 14: A diagram illustrates the changes and adjustments of the orientations of qiblah and mosques in Cairo by mathematical procedures.

From the above mentioned, it is clear that the astronomical phenomena affected the construction of the Fatimid mosques in Cairo [303-304](u), including the mosque of Al-Hakim bi-Amr Allah [296-299](s), as well as Al-Azhar mosque [300-301](t), which were built at a deviation of 10 degrees to the main planning of the street, this was according to the astronomical calculations of the Qiblah direction. Furthermore, it was observed that the prayer area of al-Azhar mosque was crossed by a passage at right angles to the Qibla direction; this is similar to the Fatimid architectural design of the great mosque of Mahdiya in Tunisia [9, 305-306](v). As for the Mamluk religious architecture in Cairo [10, 307-308](w), the exterior layout of the main street was arrange and aligned with the astronomical phenomena calculations of the Qiblah direction. Regarding to the city of the dead or the so-called Al-Qarafa of Cairo [294-295](r), it is observed that the main layout axis of AlQarafa and most of the surrounding mosques were oriented in a southwards, this is due to the astronomical phenomena accounts of the Qiblah direction, where the internal and external layouts of Al-Qarafa and its architectural components were roughly arranged and aligned with the astronomical direction of the Qiblah[138, 169, 266]. In accordance with the Egyptian historian Al-Maqrizi and the fifteenth century sources $[138,266]$, there are different directions for the qiblah in Cairo-Egypt as shown in the following diagram (Figure 15).

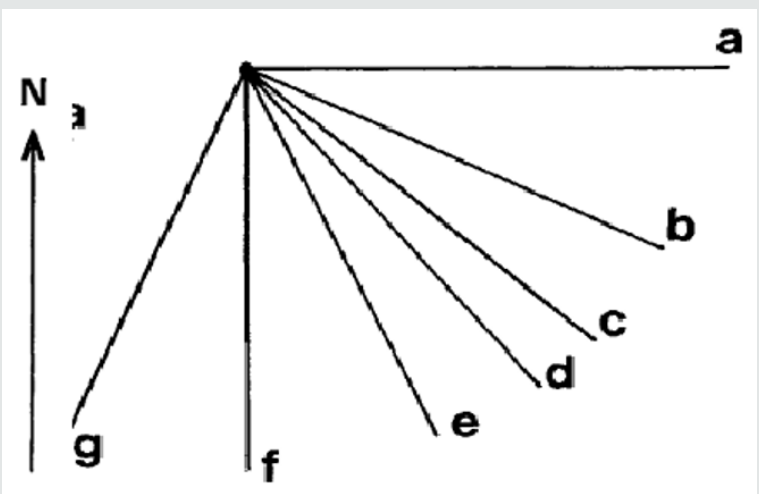

Figure 15: A diagram clarifies the qiblah directions and the mosques orientations in Cairo according to astronomical sources, where there were different directions and various deviations.

In the previous diagram (Figure 15), it is clear that in (a) of the diagram, the qiblah directions adjusted according to the east, in (b) of the diagram, the direction detected due to winter sunrise, in (c), the direction regulated by the astronomer Ibn Yunus, and from (e) to (g), the direction adjusted according to the rising and setting of Canopus / Suhayl [138, 266] (Figures 5-7, 13). It is worth mentioning that in some Mamluk religious architecture bordering the main road of the Fatimid city, like the madrassa and mausoleum of Al-Nasir Muhammad [309-310](x) dating back to the early fourteenth century (Figure 16).
The previous design (Figure 16), it is clear that the external wall of the madrasa was aligned or arranged according to the main street planning, and was vertical to the qiblah of $\mathrm{Al}$ sahabah in a straight line at an angle of 90 degrees, while the facade of the madrassa was not aligned to the street planning, but rather to the axis of the city, and the external and the inner of the facade wall were inclined to each other at about 10 degrees, and this was the deviation and variation between the two qiblas of $\mathrm{Al}$ sahabah and astronomers $[138,169,266]$, where it is observed that the facade of this madrassa and mausoleum was aligned or arranged in a straight line according 
to the street, however the inner part of this building was inclined to the orientation of the qiblah that was astronomically adjusted, and this was in order to align or arrang the the external parts of this buildings with the true qiblah of $\mathrm{Al}$ sahabah $[138,169,266]$ (Figure 17).

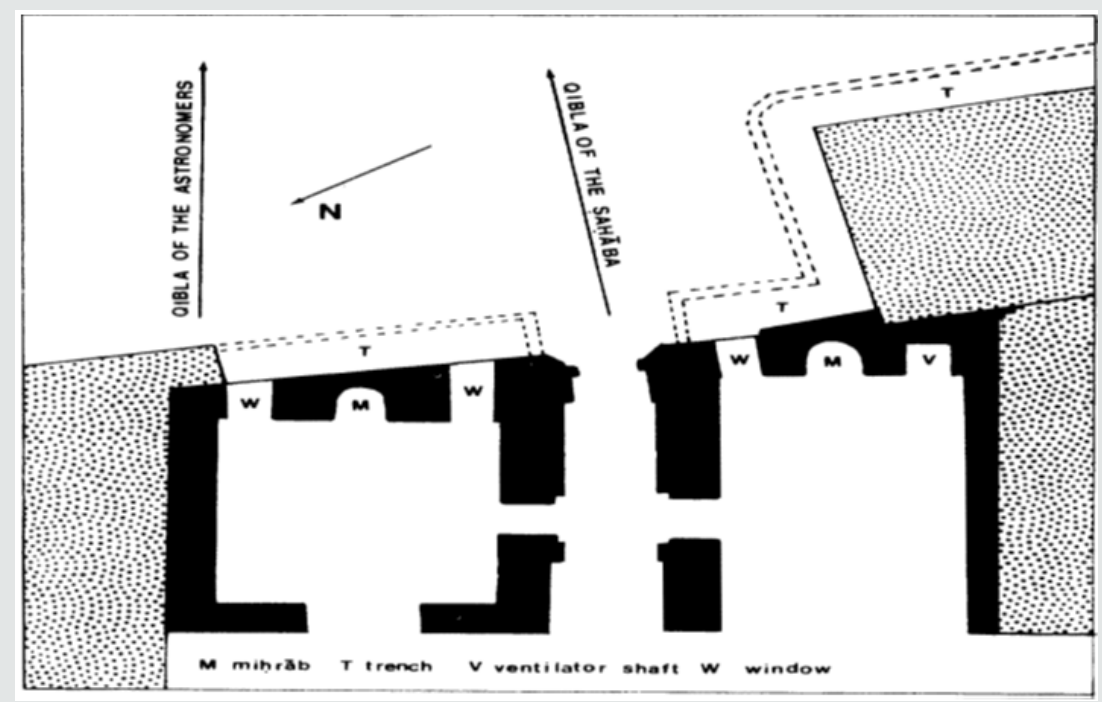

Figure 16: A design for Al-Nasir Muhammad madrassa.

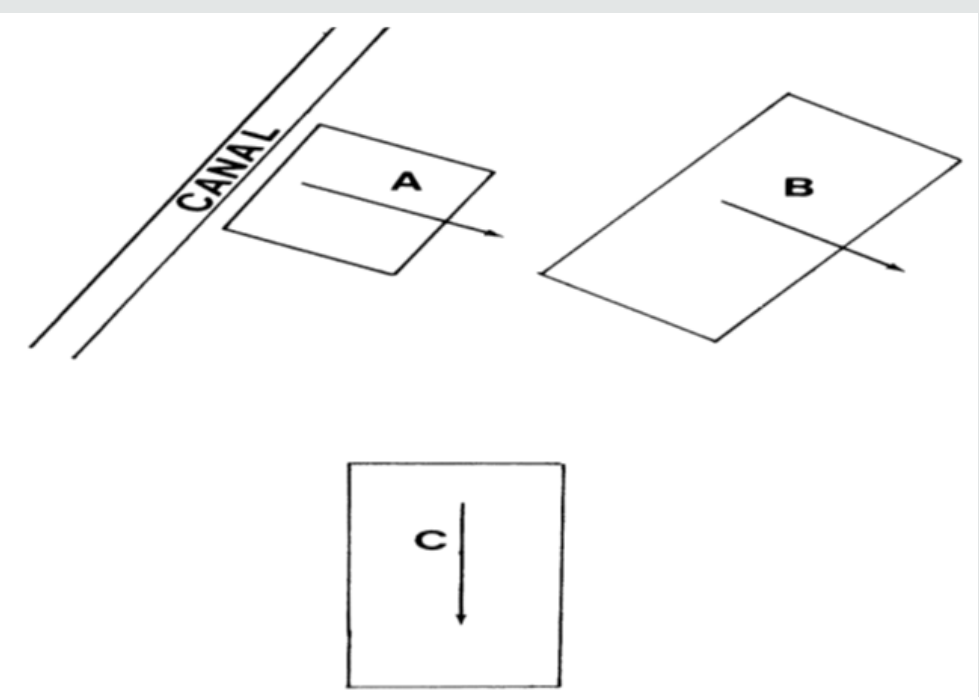

Figure 17: A diagram illustrates orientations of the qiblah in three main areas.

The previous diagram (Figure 17), it is clear that the Fatimid city (A), which was aligned with the qiblah of Al sahabah, while the Mamluk religious architecture(B) was aligned with the qiblah of the astronomers that mathematically determined, and the city of the dead or the area of Al-Qarafa (C) was aligned towards the south $[138,169,266]$ (Figures 4-7, 11-13). From the above mentioned, it is clear that there were differences and deviations in the directing procedures throughout the ages of Islamic religious architecture, and this is due to the influences of astronomical phenomena on Islamic architecture in general, and on Islamic religious architecture of Cairo in particular.

\section{Conclusion and Analysis of the Study}

The Islamic architecture and Heritage structures included numbers of scientific applied manifestations and astronomical phenomena. One of these architectural manifestations is the astronomical phenomena that have not been discussed deeply and have not been concentrated and strongly investigated by researchers. This study seeks to discuss the extent of effect of astronomical phenomena on Islamic architecture that include a vast layout of architectural styles and structural designs which were varied from one structure to other building through the different Islamic ages. The main Islamic architectural models 
include religious, funeral, civil, urban and military architectures such as Mosques, Mausoleums, Khanqahs, Zawiyas, Madrassas, Palaces, Turrets or Towers, Castles and Fortresses, in addition to domestic architecture that includes the public baths or the socalled Hammams, Fountains, Sabils and Kuttabs. For all these architectural models and structural designs of buildings, the Islamic and Heritage styles of architecture created and developed precious astronomical techniques, which were necessary to construct these architectures. But due to the wide content of the idea of this study, the topic will be limited on the influences of astronomical phenomena on Islamic architecture, analytical and applied study on selected religious architectural models in Cairo. There are many questions arose when studying the influences of astronomical phenomena on Islamic architecture and Heritage structures, the answers to these questions proved that the astronomy is one of the oldest and important natural sciences, and it also has significant contributions to Islamic civilization. The Muslim astronomers have many contributions, where they were aware of astronomical phenomena and studied the astronomical models of stars and planets in the Ptolemaic period, also improved the techniques of mathematical calculation and computation ways, in addition to develop the methods of observation, as well as creating precious observational tools, they also founded extensive observatories, in addition to improvement of planetary models in order to observe, monitor and control movement and shifts of constellations, stars and planets in accordance with the evolution of cosmology. The contributions of Muslim astronomers arrived its highest point during the so-called Islamic Golden Age (during the 8th -13th centuries), where the Islamic world was seen as a scientific center of innovations and discoveries. The contributions of Muslim astronomers were extended over a wide area of the Arab lands, where the names of these Muslim scientists became known for their valuable astronomical observations and scientific calculations, which were the main cause for the emergence of the light of astronomy during the modern times. There are prominent Muslim astronomers, who are the pioneers of astronomy throughout Islamic times, where there are many important astronomers, but to mention not exclusively, for example Al-Khwarizmi (ca. 780-850), Al-Battani (ca. 858 - 929), Al-Sufi (ca. 903- 986), Ibn Yunus (ca.9501009), Al-Biruni (ca. 973-1050), and Omar al- Khayyam (ca.10481131). During the 8th-15th centuries, there were some benefits of astronomy and astronomers, which were carried through precious observations and exact monitoring of cosmic phenomena and celestial objects, resulting in valuable astronomical tables that benefit Islamic architecture. Later, the Islamic astronomy has a great impact on other astronomical features that prevailed in other countries across the world such as the astronomy of Byzantine Empire, Indian astronomy, Chinese and European astronomy, where there are a great number of names of stars and constellations are still known by their Arabic names. From the 8th-15th centuries, there were nearly ten thousands manuscripts related to Islamic astronomical phenomena and approximately more than a thousand tools linked to astronomical phenomena during the Islamic ages, which are kept in museums and libraries of Near, Middle and Far East, as well as in different counties around the world. The most important features of Islamic astronomy and what related to astronomical phenomena are the models of astronomical tools and how to apply astronomical techniques in different fields of religious beliefs and rituals during the different Islamic ages. Moreover, the Islamic calendar, or the so-called Islamic lunar calendar that depends on the phases of the moon, and from an astronomical point of view, it relates to the times of prayer, as well as the direction of Qiblah, where it must be oriented towards the direction of the Sacred Mosque of Kaa'ba at Mecca, in addition to the only important architectural requirement in any mosque is to correctly directed towards the Qiblah of Kaa'ba. The locating, monitoring, directing and determining for the true direction of the Qiblah was an important matter and critical issue of the Islamic architectural scientific studies and for Muslim astronomers throughout the Islamic ages. There are some links and requirements associated with the manifestations of Islamic astronomy, which can be addressed through the astronomical phenomena that require survey and surveyor, geography and geographer, mathematics and mathematician, in addition to scientific observations of astronomical phenomena related to astronomy and astronomer, as well as astrology and astrologer. Furthermore, there are scientific studies conducted by Muslim astronomers throughout the Islamic ages and related to orientation schedules of the Qiblah. The mosques and madrasas in Cairo, which were from early Mamluk age upwards used astronomical tables related with astronomical phenomena, this was in order to determine time by the sun and to regulate the five daily prayers times, which linked to the science of timing or the so-called muwaqit. Some of these astronomical tables were collected by the Fatimid astronomer called Ibn Yunus, and other astronomical tables were gathered by different Mamluk astronomers. One of these tables regulates the altitude or the rise of the sun in points or degrees and minutes that agree almost exactly to each day of the solar year. There are many astronomical influences that are closely linked to Islamic architecture, which was resulted from the idea and through the process of linking the architectural structures of the earth with the celestial objects. The influences are emerged through the ideas and concepts of linking between the designs of architecture and some astronomical phenomena that are related to the apparent movement of the sun and the moon in particular, or some other constellations and planets that could not be seen with the naked eye. The astronomical phenomena were used by Muslim astronomers in monitoring and directing the Qiblah of mosques to Mecca, as well as these astronomical phenomena were influential factors in determining prayer times, for this purpose, the astronomers used an effective method called sundials, which were particularly used in determining prayer times of Dhuhr (midday) and 'Asr (afternoon). In Islamic 
religious architecture of Cairo, the sundials were used effectively, for example but not limited to the marble sundial of Al-Azhar mosque, and the sundial of mosque of Muhammad Bey Abu alDhahab. The seventh century $\mathrm{AH}$ is one of the most important historical periods in the construction of Islamic observatories, where the construction of an observatory was built at this time in the city of Tabriz, known as the Maragha observatory that was one of the historical capitals of Iran, which was managed by many Muslim astronomers such as Nasir al-Din al-Tusi (ca. 1201-1274). Islamic architecture was influenced by astronomical objects, celestial bodies and cosmic phenomena, which lie in the knowledge of Muslim astronomers and architects of importance and significance of cosmic phenomena, celestial objects, astronomical manifestations that influenced the architectural characteristics of Islamic architecture, in addition to how to benefit from these phenomena in the processes of architectural construction, as well as how to take advantage of these phenomena and manifestations in structural and geometrical building designs. Examples of these astronomical phenomena lie in the use of astronomical phenomena to determine the exact and correct direction of the Qiblah, also the use of sundials and astrolabes in mosques to adjust prayer times, as well as tracking and monitoring the movement of celestial objects in their cosmic cycles and astronomical phases, in addition to observing, tracking and monitoring the motion of the sun, as well as the orbits and phases of the moon, this in order to be used in the process of timekeeping and to be benefited from them in adjusting prayer times, where there is a need for determining and adjusting the time of certain acts of worship in Islamic beliefs, such as prayer times associated with the movement of the sun, as well as the length of shadows that were differentiated. It is worth mentioning that some acts of worship in Islamic beliefs such as fasting or Sawm, Hajj, and Zakat or Zakah that were associated with monitoring the crescent, or the so-called crescent observation and also linked to determining the beginnings and ends of Arab months. There are many Islamic architectural models that have been closely associated with astronomical phenomena, for example but not limited to the first mosques were established in Islamic times depending on some cosmic and astronomical phenomena such as the sun, moon, stars and winds, which were the most practical methods to find thedirection of the Qiblah. These astronomical phenomena were also used to determine and adjust the calendar, whether it be solar, lunar, astral, agricultural and religious, as well as these phenomena used in reckoning the times of day and night-time, this was by the length of the shadow, in addition to the locations, phases and passes of the moon and the sun, where from fourteen centuries ago, there were many verses in the Qur'an that describe how Allah created the cosmic and astronomical phenomena. It is known that the stars are raised and dropped at specific ranges on the horizon for a certain location, where at the time of the equinoxes, the rise and set of the sun determine the east and west, and the locations of the sunrise and sunset at the solstices will be about 30 degrees in a northward position or direction in middle of the summer, and about 30 degrees in a southward position or direction in middle of the winter. In North West Africa, the Qiblah will be towards the sunrise at the time of the equinoxes; in Egypt, the Qiblah will be towards the sunrise at the time of the middle of the winter; in Syria, the Qiblah will be towards the rise of the star known as Canopus; in Iraq, the Qiblah will be towards the sunset at the time of the middle of the winter; in India, the Qiblah will be towards the sunset at the time of the equinoxes; in Yemen, the Qiblah will be in the direction in which the northern wind blowing, which will be towards the polar star that does not rise nor fall, however its location in the north. From the above, it is clear that the astronomical phenomena have affected the architecture of mosques, as well as the design of Islamic structures and cities, which were associated with the detection and control in the direction of the Qiblah. It is worth mentioning that some of the first mosques were directed towards the sunrise in winter time, this is due to the belief that makes the walls of the Qiblah are paralleled into the northwest wall of the Kaa'ba, and this applies to some of the oldest mosques established in Egypt like the mosque of Amr ibn al-'as in Fustat. However, the major mosque should face the vertical direction of sunrise in summer time, where the same direction was identical to the northwestern wall of the Kaa'ba .The direction of qiblah and the orientation of the first mosque built in Al Fustat, Cairo- Egypt, which oriented to the sunrise in the winter season, where this mosque was constructed in the winter season of the year 641-642, so the qiblah was in the direction of sunrise in the winter at about 27 degrees southeast. It is clear that the influences of astronomical phenomena, including constellations and stars such as Canopus, known as Suhayl, along with the azimuth of sunrise and sunset, and the azimuth for the star Canopus, which were affected on the Kaa'ba and on the sacred geography of Makkah. After $623 \mathrm{AD} /$ Second year AH, the direction of these prayers was towards the Kaaba of Makkah instead of Jerusalem; this is right direction and sacred direction to pray, known as the Qiblahand since the eighth century onwards, there were a large number of Islamic astronomical manuscripts that include tables, known as Zijes, including measurable factors used for astronomical and mathematical determination of the locations of the sun, moon, stars, constellations and planets, as well as the procedures for determining the Qiblah. From the above mentioned, there are some factors linked to the influences of astronomical phenomena on Islamic religious architecture in general, and the architecture of mosques in particular, including sacred geography and topography of Makkah and related methods of directing towards the Kaa'ba, constellations and stars such as Canopus, known as Suhayl which is the brightest star in the southern sky of Makkah, along with the summer and winter sunrise or sunset, summer and winter solstices, the cardinal directions and monsoon, and the orientation of mosques towards the qiblah and mihrab. There were several directions for the qiblah that used in the mosques of Cairo-Egypt, and when the historian called Al-Maqrizi 
discussed the deviations of the mihrabs in Islamic mosques in Egypt, he identified at least four different orientations for the mihrabs; the first direction of the qiblah was in the mosque of Amr in Al Fustat in accordance with the sunrise in winter season at about 117 degrees, this was known as the qiblah of Al sahabah or the companions of the Prophet, while the second direction of the qiblah and orientation of the mihrab was in the mosque of Ibn Tulun at about 141 degrees south of the qiblah of astronomers that was calculated mathematically; the third qiblah direction was in the mosque of Al Azhar that was also adjusted and calculated mathematically, and the fourth qiblah direction and orientation of the mihrab was in the city of the dead, or the so-called Al-Qarafa of Cairo, the main layout axis of Al-Qarafa and most of the surrounding mosques were oriented in a southwards, this is due to the astronomical phenomena accounts of the Qiblah direction, where the internal and external layouts of Al-Qarafa and its architectural components were roughly arranged and aligned with the astronomical direction of the Qiblah. From the above mentioned, it is clear that the astronomical phenomena affected the construction of the Fatimid mosques in Cairo, including the mosque of Al-Hakim bi-Amr Allah, as well as Al-Azhar mosque, which were built at a deviation of 10 degrees to the main planning of the street, this was according to the astronomical calculations of the Qiblah direction. Furthermore, it was observed that the prayer area of al-Azhar mosque was crossed by a passage at right angles to the Qiblah direction; this is similar to the Fatimid architectural design of the great mosque of Mahdiya in Tunisia. As for the Mamluk religious architecture in Cairo, the exterior layout of the main street was arrange and aligned with the astronomical phenomena calculations of the Qiblah direction. Regarding to the city of the dead, or the socalled Al-Qarafa of Cairo, where the main layout axis of Al-Qarafa and most of the surrounding mosques were oriented in a southwards, this is due to the astronomical phenomena accounts of the Qiblah direction, where the internal and external layouts of AlQarafa and its architectural components were roughly arranged and aligned with the astronomical direction of the Qiblah. In accordance with the Egyptian historian Al-Maqrizi and the fifteenth century sources, there are different directions for the qiblah in Cairo-Egypt, where the first qiblah direction was adjusted according to the east, the second qiblah direction was detected due to winter sunrise, the third qiblah direction was regulated by the astronomer Ibn Yunus, and other qiblah directions were adjusted according to the rising and setting of Canopus/Suhayl. From the above mentioned, it is clear that there were differences and deviations in the directing procedures throughout the ages of Islamic religious architecture, and this is due to the influences of astronomical phenomena on Islamic architecture in general and on Islamic religious architecture of Cairo in particular.

\section{Results of the Study}

1. The astronomy is one of the oldest and important natural sciences, and it also has significant contributions to Islamic civilization. The Muslim astronomers have many contributions, where they were aware of astronomical phenomena and studied the astronomical models of stars and planets in the Ptolemaic period, also improved the techniques of mathematical calculation and computation ways, in addition to develop the methods of observation, as well as creating precious observational tools, they also founded extensive observatories, in addition to improvement of planetary models in order to observe, monitor and control movement and shifts of constellations, stars and planets in accordance with the evolution of cosmology. The contributions of Muslim astronomers arrived its highest point during the so-called Islamic Golden Age (during the 8th -13th centuries), where the Islamic world was seen as a scientific center of innovations and discoveries.

2. There are prominent Muslim astronomers, who are the pioneers of astronomy throughout Islamic times, where there are many important astronomers, but to mention not exclusively, for example Al-Khwarizmi (ca. 780-850),Al-Battani (ca. 858 - 929), Al-Sufi (ca. 903- 986), Ibn Yunus (ca.950-1009), Al-Biruni (ca. 973-1050), and Omar al- Khayyam (ca.1048-1131). Throughout the 8th-15th centuries, there were some benefits of astronomy and astronomers, which were carried through precious observations and exact monitoring of cosmic phenomena and celestial objects, resulting in valuable astronomical tables that benefit Islamic architecture.

3. The Islamic astronomy has a great impact on other astronomical features that prevailed in other countries across the world such as the astronomy of Byzantine Empire, Indian astronomy, Chinese and European astronomy, where there are a great number of names of stars and constellations are still known by their Arabic names. From the 8th-15th centuries, there were nearly ten thousands manuscripts related to Islamic astronomical phenomena and approximately more than a thousand tools linked to astronomical phenomena during the Islamic ages, which are kept in museums and libraries of Near, Middle and Far East, as well as in different counties around the world.

4. The most important features of Islamic astronomy and what related to astronomical phenomena are the models of astronomical tools and how to apply astronomical techniques in different fields of religious beliefs and rituals during the different Islamic ages. Moreover, the Islamic calendar or the so-called Islamic lunar calendar that depends on the phases of the moon, and from an astronomical point of view, it relates to the times of prayer, as well as the direction of Qiblah, where it must be oriented towards the direction of the Sacred Mosque of Kaa'ba at Mecca, in addition to the only important architectural requirement in any mosque is to correctly directed towards the Qiblah of Kaa'ba.

.5. The locating, monitoring, directing and determining for the true direction of the Qiblah was an important matter and critical issue of the Islamic architectural scientific studies and for Muslim 
astronomers throughout the Islamic ages. There are some links and requirements associated with the manifestations of Islamic astronomy, which can be addressed through the astronomical phenomena that require survey and surveyor, geography and geographer, mathematics and mathematician, in addition to scientific observations of astronomical phenomena related to astronomy and astronomer, as well as astrology and astrologer.

6. There are scientific studies conducted by Muslim astronomers throughout the Islamic ages and related to orientation schedules of the Qiblah. The mosques and madrasas in Cairo, which were from early Mamluk age upwards used astronomical tables related with astronomical phenomena, this was in order to determine time by the sun and to regulate the five daily prayers times, which linked to the science of timing or the so-called muwaqit. Some of these astronomical tables were collected by the Fatimid astronomer called Ibn Yunus, and other astronomical tables were gathered by different Mamluk astronomers. One of these tables regulates the altitude or the rise of the sun in points or degrees and minutes that agree almost exactly to each day of the solar year.

7. There are many astronomical influences that are closely linked to Islamic architecture, which was resulted from the idea and through the process of linking the architectural structures of the earth with the celestial objects. The influences are emerged through the ideas and concepts of linking between the designs of architecture and some astronomical phenomena that are related to the apparent movement of the sun and the moon in particular, or some other constellations and planets that could not be seen with the naked eye. The astronomical phenomena were used by Muslim astronomers in monitoring and directing the Qiblah of mosques to Mecca, as well as these astronomical phenomena were influential factors in determining prayer times, for this purpose, the astronomers used an effective method called sundials, which were particularly used in determining prayer times of Dhuhr (midday) and 'Asr (afternoon). In Islamic religious architecture of Cairo, the sundials were used effectively, for example but not limited to the marble sundial of Al-Azhar mosque, and the sundial of mosque of Muhammad Bey Abu al-Dhahab.

8. There are many Islamic architectural models that have been closely associated with astronomical phenomena, for example but not limited to the first mosques were established in Islamic times depending on some cosmic and astronomical phenomena such as the sun, moon, stars and winds, which were the most practical methods to find the direction of the Qiblah. These astronomical phenomena were also used to determine and adjust the calendar, whether it be solar, lunar, astral, agricultural and religious, as well as these phenomena used in reckoning the times of day and night-time, this was by the length of the shadow, in addition to the locations, phases and passes of the moon and the sun, where from fourteen centuries ago, there were many verses in the Qur'an that describe how Allah created the cosmic and astronomical phenomena.

9. In North West Africa, the Qiblah will be towards the sunrise at the time of the equinoxes; in Egypt, the Qiblah will be towards the sunrise at the time of the middle of the winter; in Syria, the Qiblah will be towards the rise of the star known as Canopus; in Iraq, the Qiblah will be towards the sunset at the time of the middle of the winter; in India, the Qiblah will be towards the sunset at the time of the equinoxes; in Yemen, the Qiblah will be in the direction in which the northern wind blowing, which will be towards the polar star that does not rise nor fall, however its location in the north. Some of the first mosques were directed towards the sunrise in winter time, this is due to the belief that makes the walls of the Qiblah are paralleled into the northwest wall of the Kaa'ba, and this applies to some of the oldest mosques established in Egypt like the mosque of Amr ibn al-'as in Fustat. However, the major mosque should face the vertical direction of sunrise in summer time, where the same direction was identical to the northwestern wall of the Kaa'ba .The direction of qiblah and the orientation of the first mosque built in Al Fustat, Cairo- Egypt, which oriented to the sunrise in the winter season, where this mosque was constructed in the winter season of the year 641-642, so the qiblah was in the direction of sunrise in the winter at about 27 degrees southeast.

10. There are some factors linked to the influences of astronomical phenomena on Islamic religious architecture in general, and the architecture of mosques in particular, including sacred geography and topography of Makkah and related methods of directing towards the Kaa'ba, constellations and stars such as Canopus, known as Suhayl which is the brightest star in the southern sky of Makkah, along with the summer and winter sunrise or sunset, summer and winter solstices, the cardinal directions and monsoon, and the orientation of mosques towards the qiblah and mihrab. There were several directions for the qiblah that used in the mosques of Cairo-Egypt, and there were at least four kinds of deviations of the mihrabs in Islamic mosques in Egypt; the first was in the mosque of Amr in Al Fustat, while the second direction of the qiblah and orientation of the mihrab was in the mosque of Ibn Tulun, the third qiblah direction was in the mosque of Al Azhar, and the fourth qiblah direction and orientation of the mihrab was in the city of the dead, or the so-called Al-Qarafa of Cairo.

11. The astronomical phenomena affected the construction of the Fatimid mosques in Cairo, including the mosque of Al-Hakim bi-Amr Allah, as well as Al-Azhar mosque, and the prayer area of al-Azhar mosque was crossed by a passage at right angles to the Qiblah direction; this is similar to the Fatimid architectural design of the great mosque of Mahdiya in Tunisia. The Mamluk religious architecture in Cairo, the exterior layout of the main street was arrange and aligned with the astronomical phenomena calculations of the Qiblah direction, and it is clear that there were differences and deviations in the directing procedures throughout the ages of 
Islamic religious architecture, and this is due to the influences of astronomical phenomena on Islamic architecture in general, and on Islamic religious architecture of Cairo in particular.

\section{Endnotes}

[a] There are many important references in the field of Islamic architecture, but to mention not exclusively, for example; Hope, T., (1835), An Historical Essay on Architecture, John Murray, London; Saladin, H., (1899), La Grande Mosquée de Kairwan, Picard, Paris; Creswell, K., (1978). Muslim Architecture of Egypt, Hacker Art Books, New York; Hakim, B., (1986), Arabic Islamic Cities: Buildings and Planning Principles, Kegan Paul, London; Doris, B.A., (1989). Islamic Architecture in Cairo, E.J. Brill, Leiden; Meinecke, M., (1992). Die Mamlukische Architektur in Ägypten und Syrien (648/1250 bis 923/1517), 2 Vols, Glückstadt; Williams, C., (2002). Islamic Monuments in Cairo: The Practical Guide, American University in Cairo Press, Egypt; Lowney, Ch., (2006). A Vanished World: Muslims, Christians, and Jews in Medieval Spain, Oxford University Press, Oxford; Mintz, J., (2010). The Umayyad Dome of the Rock: A Historical Narrative through Architecture, California State University, USA.

[b] For more information about Al-Khwarizmi See: Dunlop, D.M., (1943). Muhammad b. Mūsā al-Khwārizmī, The Journal of the Royal Asiatic Society of Great Britain and Ireland, Vol.2, pp. 248-250; Arndt, A., (1983). Al-Khwarizmi, The Mathematics Teacher, Vol.76, Issue 9, pp.668-670; Saliba, G., (1998). Science and medicine, Iranian Studies, Vol.31, Issue 3/4, pp.681690;Hogendijk, J.P. (1998). al-Khwarizmi, Pythagoras, Vol.38, Issue 2, pp.4-5; Brentjes, S., (2007).Khwārizmī: Muhammad ibn Mūsā al-Khwārizmī, In: Hockey, Th., et al.(eds.). The Biographical Encyclopedia of Astronomers, Springer Reference, Springer, New York, pp. 631-633; Oaks, J., (2009). Polynomials and equations in Arabic algebra, Archive for History of Exact Sciences, Vol.63, Issue 2, pp.169-203.

[c] For more information about Al-Battani See: Nallino, C.A., (1960). Al-Battānī, In: Encyclopaedia of Islam, 2nd ed. Vol. 1, E. J. Brill, Leiden, pp. 1104-1105; Schlager, N., \& Lauer, J., ( 2001). Science and Its Times: 700-1449, Gale Group, Michigan, p.291; Griffin, R., (2006). Education in the Muslim World: different perspectives, Symposium Books Ltd., Oxford, p. 31; van Benno, D., (2007). Battānī: Abū 'Abd Allāh Muhammad ibn Jābir ibn Sinān al-Battānī al-Ḥarrānī al-Ṣābi', In: Hockey, Th., et al. (Eds.). The Biographical Encyclopedia of Astronomers, Springer, New York, pp. 101-103; Nallino, C.A.,(2012), al-Battānī, In: Bearman, P., Bianquis, Th., Bosworth, C.E., van Donzel, E., Heinrichs, W.P., Encyclopaedia of Islam, 2nd ed., E. J. Brill, Leiden; Angelo, J.A., (2014). Encyclopedia of Space and Astronomy, Infobase Publishing, New York, p.78.

[d] For more information about Al-Sufi See: Steinschneider,M., (1864). Ueber die Mondstationen (Naxatra), und das Buch
Arcandam, Zeitschrift der Deutschen Morgenländischen Gesellschaft, Vol. 18, Harrassowitz Verlag Press, Germany, pp.118-201; Steinschneider, M., (1871). Zur Geschichte der Uebersetzungen aus dem Indischen ins Arabische und ihres Einflusses auf die arabische Literatur; insbesondere über die Mondstationen (Naxatra) und darauf bezügliche Loosbücher, Zeitschrift der Deutschen Morgenländischen Gesellschaft, Vol.25, Harrassowitz Verlag Press, Germany, pp. 378-428; Suter, H., (1892).Das Mathematiker-Verzeichniss im Fihrist des Ibn Abî Ja'ḳûb an-Nadîm: Zum ersten Mal vollständig ins Deutsche überstetzt und mit Anmerkungen versehen, Abhandlungen zur Geschichte der Mathematik, Vol.6 = supplement to Zeitschrift für Mathematik und Physik, Vol.37, pp.1-87;Suter,H.,(1900).Die Mathematiker und Astronomen der Araber und ihre Werke, Abhandlungen zur Geschichte der mathematischen Wissenschaften mit Einschluß ihrer Anwendungen, Vol.10 = supplement to Zeitschrift für Mathematik und Physik,Vol.45,pp.62-63;Suter, H., (1902). Nachträge und Berichtigungen zu Die Mathematiker und Astronomen der Araber und ihre Werke, Abhandlungen zur Geschichte der mathematischen Wissenschaften mit Einschluss ihrer Anwendungen, Vol.14, pp.155-185; Suter, H.,(1913). Abd al-Raḥmān b. 'Umar al-Ṣūfĩ, In: The Encyclopaedia of Islam,Vol.I, E.J.Brill, Leiden,p.57;Brockelmann, C.,(1937). Geschichte der arabischen Literatur: Erster Supplementband, Vol. 1, E.J. Brill,Leiden, p. 398; Brockelmann, C., (1943). Geschichte der arabischen Literatur: Zweite den Supplementbänden angepasste Auflage, Vol. 1, E.J. Brill, Leiden, pp. 253-254; Storey, Ch., (1958). Persian Literature: A Bio-Bibliographical Survey, Vol. II, part1,Luzac \& Co., Ltd., London,pp. 41-42 (no. 75);Sayıll, A., (1960). The Observatory in Islam and its Place in the General History of the Observatory, Türk Tarih Kumuru Basımevi, Ankara $=$ Publications of the Turkish Historical Society, Series VII, no. 38, pp. 104-107; Stern,S.M., (1960). Abd al-Raḥmān b. 'Umar al-Ṣūfī, In: The Encyclopaedia of Islam, New Edition, Vol.I, E.J. Brill,Leiden, pp. 86-87; Dodge, B.,(1970). The Fihrist of alNadīm: A Tenth-Century Survey of Muslim Culture,Columbia University Press, New York=Records of Civilization: Sources and Studies, No. LXXXIII, Vol.II,pp.669-670;Sezgin,F.,(1974). Geschichte des arabischen Schrifttums, Vol. 5, Mathematik bis ca. 430 H, E.J. Brill,Leiden,pp.309-310, 426;Suter,H.,(1986). Beiträge zur Geschichte der Mathematik und Astronomie im Islam, Institut für Geschichte der arabisch-islamischen Wissenschaften, Vol. 1, Frankfurt, pp. 286-314, 315-404.

[e] For more information about Ibn Yunus See: King, D.,(1970). Ibn Yunus, The Dictionary of Scientific Biography, New York; North, J.,(1994). The Fontana History of Astronomy and Cosmology, London; King,D., (2007). Ibn Yūnus: Abū alHasan Alī ibn Abd al-Raḥmān ibn Aḥmad ibn Yūnus al-Ṣadafī, In: Hockey, Th., et al. (Eds.).The Biographical Encyclopedia of Astronomers, Springer, New York, pp. 573-574. 
[f] For more information about Al-Biruni See: Bosworth, C. E., (1968). The Political and Dynastic History of the Iranian World (A.D. 1000-1217),In: Boyle, J.A., (ed.). The Cambridge History of Iran, The Saljuq and Mongol Periods, Vol. 5, Cambridge University Press, p.7; Kennedy, E.S., (1975). The Exact Sciences, In: Frye, R. N., \& Fisher, W.B., (eds.). The Cambridge History of Iran: The period from the Arab invasion to the Saljuqs, Cambridge University Press,p.394;Rahman, H. U., (1995), A Chronology of Islamic History: 570-1000 CE, Mansell Publishing, London, p.167; Samian, A.L., (1997). Al-Biruni, In: Selin, H., (Ed.).Encyclopaedia of the History of Science, Technology, and Medicine in Non-Westen Cultures, Springer Science \& Business Media, New York, p.157; Waardenburg, J., (1999). Muslim Perceptions of Other Religions: A Historical Survey, Oxford University Press, Oxford, p.27; Khan, M. A., (2001). Al-Biruni's Discovery of India: An Interpretative Study, IAcademic Books, USA, p. 11.

[g] For more information about Sundials See: Berggren, L., (2001). Sundials in Medieval Islamic Science and Civilization,the Journal of Compendium, Vol.8, Issue 2, pp.8-14; Hogendijk, J.P., (2001). The Contributions by Abū Nașr Ibn 'Irāq and Alșaghānī to the Theory of Seasonal Hour Lines on Astrolabes and Sundials. Zeitschrift für Geschichte der Arabisch-Islamischen Wissenschaften, Vol.14, pp. 1-30; Al-Khwārizmī, (1983). Construction of Hours on the Plane of Sundials, Translated by: al-Dabbagh, J., and Commentary by: al-Dabbagh, J., \& Rosenfeld, B.A., Muhammad ibn Musa al-Khwarizmi; On the 1200th Anniversary of his Birthday, Nauka, Moscow, pp.221-234; Rosenfeld, B.A., (2008) Sundials in Islam, In: Selin, H.,(Ed.), Encyclopaedia of the History of Science, Technology, and Medicine in Non-Western Cultures, Springer, Dordrecht, pp.3338.

[h] For more information about the sundial of Muhammad Bey Abu al-Dhahab Mosque See: Crecelius, D., (1978).The Waqf of Muhammad Bey Abu al-Dhabab, Journal of the American Research Center in Egypt, Vol. 25, pp. 83-105;Crecelius, D., (1979).The Waqf of Muhammad Bey Abu al-Dhabab, Journal of the American Research Center in Egypt, Vol.26, pp.125146;Ülkü, B.,(1991).Façades in Ottoman Cairo, In: Bierman, I.\& Preziosi, D., (Eds.), The Ottoman city and its parts: Urban Structure and Social Order, A.D. Caratzas Press, New York,pp.129-172.

[i] For more information about the significance and different types of Mizwalah known as Sundial See: Michnik, H., (1923). Theorie einer Bifilar-Sonnenuhr, Astronomishe Nachrichten, Vol. 217, No. 5190, pp.81-90;Cousins,F.W.,(1973). Sundials:The Art and Science of Gnomonics, Pica Press,New York,pp.189-195;Sawyer,F.,(1978).Bifilar gnomonics, Journal of the British Astronomical association, Vol.88, Issue 4,pp.334351; Schaldach, K., (2004).The arachne of the Amphiareion and the origin of gnomonics in Greece, Journal for the History of Astronomy, Vol.35, pp.435-445; Vodolazhskaya, L.,(2013). Analemmatic and Horizontal Sundials of the Bronze Age (Northern Black Sea Coast), Archaeoastronomy and Ancient Technologies, Vol.1,Issue 1,pp.68-88.

[j] For more information about astrolabes See: Kunitzsch, P., (1981). On the authenticity of the treatise on the composition and use of the astrolabe ascribed to Messahalla, Archives Internationales d'Histoire des Sciences Oxford, Vol.31, Issue 106, pp. 42-62;King, D., (1981). The Origin of the Astrolabe According to the Medieval Islamic Sources, Journal for the History of Arabic Science, Vol.5, pp.43-83; Laird, E., (1997). Astrolabes and the Construction of Time in the Late Middle Ages, In: Carol, P., \& Richard. U., (Eds.), Constructions of Time in the Late Middle Ages, Northwestern University Press, Evanston, pp. 51-69.

[k] For more about the Cosmic and Astronomical Theology in the Qur'an See: Ahsan, Z., (2012). The Qura'n and Laws of Planetary Motion, Revelation and Science, Vol.2, Issue 1, pp.4350; Morrison, R., (2013). Natural Theology and the Qur'an, Journal of Qur'anic Studies, Edinburgh University Press, Vol.15, Issue 1, pp.1-22.

[1] For more information about the historian and geographer"Al-Bakri" See: Lévi-Provençal, E., (1960). Abū 'Ubayd al-Bakrī, Encyclopaedia of Islam, 2nd ed., Vol.1, Brill, Leiden, pp.155-157; Vernet,J.,(1970).Bakrī, Abū 'Ubayd 'Abdallāh Ibn 'Abd al-'Azīz Ibn Muhammad,In:Gillispie, Ch.,(Ed.),Dictionary of Scientific Biography Vol.1,Charles Scribner's Sons Press, New York, pp. 413-414.

[m] For more information about the Fatimid Caliph Al-Mu'izz See: Dachraoui, F., (1993). Al-Mu'izz li-Dīn Allāh, In: Bosworth, C. E.; van Donzel, E.; Heinrichs, W. P. \& Pellat, Ch. (Eds.). The Encyclopaedia of Islam, Volume VII, E. J. Brill Press, Leiden, pp. 485-489.

[n] For more information about the historian "Al-Maqrizi" See: Rabbat, N., (2003). Who was al-Maqrizi? A Biographical Sketch, Mamluk Studies Review, Vol.VII, Issue 2, Middle East Documentation Center, the University of Chicago Press, pp.119.

[o] For more information about the mihrabs and deviations See: Diez, E., (1936). Mihrāb, Encyclopaedia of Islam,Vol.3, Brill Press, Leiden,pp. 559-565; Fehérvári, G., (1993). Mihrāb, Encyclopaedia of Islam, New edition, Vol.7, Brill Press, Leiden, pp. 7-15.

[p] For more information about Al sahabah or the companions of the Prophet See: Osman, A., (2014). Companions, In: Fitzpatrick, C., and Walker, A., Muhammad in History, Thought, and Culture: An Encyclopedia of the Prophet of God, 2 Vols., Santa Barbara, ABC-CLIO, USA. 
[q] For more information about the mosque of Ibn Tulun See: Doris, B., (1993).Early Islamic Architecture in Cairo, Islamic Architecture in Cairo: an Introduction, AUC Press, Cairo, pp. 4757.

[r] For more information the city of the dead or Al-Qarafa of Cairo See: El Kadi, G.,\& Bonnamy, A., (2007). Architecture for the Dead: Cairo's Medieval Necropolis. The American University in Cairo Press, Cairo; David, S., (2010). Understanding Cairo: The logic of a city out of control, AUC Press, Cairo, pp. 20-24.

[s] For more information about the Mosque of Al-Hakim bi-Amr Allah See: 'Abd al-Wahhab, H.,(1940). Al-'Asr alFatimi, Majallat al-Imara, Vol.2, Issue 5/6,pp.310-324; Bloom, J.,(1983).The Mosque of al-Hakim in Cairo, Muqarnas, Muqarnas: An Annual on Islamic Art and Architecture, Vol.1, pp.15-36; King,J.R.,(1984).The Restoration of the AlHākim Mosque in Cairo, Islamic Studies, Vol. 23, Issue 4, pp. 325-335;Williams,C.,\&Doris,B., (1992).Islamic Architecture in Cairo: An Introduction,Vol. III, Journal of the American Research Center in Egypt, Vol.29, pp.226-229.

[t] For more information about the Mosque of Al-Azhar See: Barraclough, S.,(1998). Al-Azhar: Between the Government and the Islamists, Middle East Journal,Vol.52, Issue 2,pp. 236-249; Rabbat,N.,(1996). Al-Azhar Mosque: An Architectural Chronicle of Cairo's History, Muqarnas- An Annual on the Visual Culture of the Islamic World, Vol.13, Brill Press, pp. 45-67.

[u] For more information about the Fatimid mosques in Cairo See: Dadoyan, S.B., \& Parsumean-Tatoyean, S., (1997). The Fatimid Armenians: Cultural and Political Interaction in the Near East, Brill, Leiden, pp. 81.ff; Jarzombek, M. \& Prakash, V., (2011). A Global History of Architecture, John Wiley \& Sons Press, USA, pp. 383-385.

[v] For more information about the great mosque of Mahdiya in Tunisia See: Doris, B., (1992). Islamic Architecture in Cairo: An Introduction, Brill, Leiden, pp.62-63; Yeomans, R., (2006). The art and architecture of Islamic Cairo, Garnet \& Ithaca Press, New York, pp. 58-60; Hadda, L., (2008). Nella Tunisia Medievale, Architettura e Decorazione Islamica(IX-XVI secolo),Liguori editore,Naples, pp.70-73.

[w] For more information about the Mamluk religious architecture in Cairo See: Meinecke, M.,(1992). Die Mamlukische Architektur in Ägypten und Syrien (648/1250 bis 923/1517), 2 Vols. J. J. Augustin, Glückstadt; Bloom, J.,(1999). Mamluk Art and Architectural History, Mamluk Studies Review, Vol. III, Middle East Documentation Center (MEDOC), the University of Chicago Press, pp.31-57; Rabbat, N., (2002). Perception of Architecture in Mamluk Sources, Mamluk Studies Review, Vol VI, Middle East Documentation Center(MEDOC), the University of Chicago Press, pp.155-176. [x] For more information about the madrassa and mausoleum of Al-Nasir Muhammad See: O'Kane, B., (2016).The Mosques of Egypt, AUC Press, Cairo, pp. 66-70; Williams, C.,(2018). Islamic Monuments in Cairo: The Practical Guide (7th ed.), AUC Press, Cairo, pp. 225-226.

\section{References}

1. Simpson MF (1913) A History of Architectural Development. Longmans, Green \& Co, London, United Kingdom.

2. Creswell KAC (1958) A Short Account of Early Muslim Architecture. Penguin Books London, United Kingdom.

3. Fletcher B (1961) A History of Architecture: On the Comparative Method. (17 ${ }^{\text {th }}$ edn.), the Athlone Press, London, United kingdom.

4. Kostof S (1994) A History of World Architecture. Oxford University Press, Oxford, United kingdom.

5. Hope T (1835) An Historical Essay on Architecture. John Murray, London, United Kingdom.

6. Saladin H (1899) La Grande Mosquée de Kairwan. Picard, Paris, France.

7. Creswell K (1978) Muslim Architecture of Egypt. Hacker Art Books, New York, USA.

8. Hakim B (1986) Arabic Islamic Cities: Buildings and Planning Principles. Kegan Paul, London, United Kingdom.

9. Doris BA (1992) Islamic Architecture in Cairo: An Introduction. Brill Press, Leiden, Netherlands.

10. Meinecke M (1992) Die Mamlukische Architektur in Ägypten und Syrien (648/1250 bis 923/1517). JJ Augustin Glückstadt, Germany.

11. Williams C (2002) Islamic Monuments in Cairo: The Practical Guide. American University in Cairo Press, Egypt.

12. Lowney Ch (2006) A Vanished World: Muslims, Christians, and Jews in Medieval Spain. Oxford University Press, Oxford, United kingdom.

13. Mintz J (2010) The Umayyad Dome of the Rock: A Historical Narrative through Architecture. California State University, USA.

14. Pingree D (1973) The Greek influence on early Islamic mathematical astronomy. Journal of the American Oriental Society 93(1): 32-43.

15. Pananides NA (1974) Introductory Astronomy. Addison-Wesley Publishing Company, California, USA.

16. Narlikar JV (1978) The Structure of the Universe. Oxford University Press, Oxford, United Kingdom.

17. Jaffereys WH, Robins RP (1981) Discovering Astronomy. John Wiley, Toronto, Canada.

18. Savage-Smith E (1985) Islamicate Celestial Globes: Their History, Construction and Use. Smithsonian Institution Press, Washington DC, USA.

19. Saliba G (2002) Greek Astronomy and the Medieval Arabic Tradition: The medieval Islamic astronomers were not merely translators. They may also have played a key role in the Copernican revolution. American Scientist 90(4): 360-367.

20. North J (2008) Cosmos: An Illustrated History of Astronomy and Cosmology. Revised Edition, The University of Chicago Press, Chicago, USA

21. Morrison R (2013) Islamic astronomy, In: Lindberg D, Shank M (Eds.) The Cambridge History of Science, Cambridge University Press, Cambridge, England.

22. Kennedy ES (1956) A Survey of Islamic Astronomical Tables; Transactions of the American Philosophical Society. American Philosophical Society, Philadelphia 46(2): 123-177. 
23. Toomer G (1990) Al Khwārizmī, Abu Jafar Muhammad ibn Mūsā, In: Gillispie, Ch, (Ed.). Dictionary of Scientific Biography. Charles Scribner's Sons, New York, USA.

24. Dallal A (1999) Science, Medicine and Technology, In: Esposito J (Ed.). The Oxford History of Islam. Oxford University Press, Oxford, United kingdom.

25. Hoskin M (2008) Book Reviews: A DSB of Astronomers. Journal for the History of Astronomy 39(135): 272-274.

26. Unsöld A, Baschek B (1991) Classical Astronomy; The Solar System. Heidelberg Science Library, Springer, Germany.

27. Van Den Bergh S (1999) The Early History of Dark Matter. Publications of the Astronomical Society of the Pacific 111(760): 657-660.

28. Hoskin M (1999) The Cambridge Concise History of Astronom. Cambridge University Press, Cambridge, England.

29. Unsöld A, Baschek B (2001) The New Cosmos: An Introduction to Astronomy and Astrophysics. Translated by Brewer WD, Springer, Germany.

30. Berrgren JL, Nathan S (2007) Aristarchus's On the Sizes and Distances of the Sun and the Moon: Greek and Arabic Texts. Archive for History of Exact Sciences 61(3): 213-254.

31. Losev A (2012) Astronomy' or 'astrology': A brief history of an apparent confusion. Journal of Astronomical History and Heritage 15(1): 42-46.

32. Swerdlow N (1973) The derivation and first draft of Copernicuss planetary theory: A translation of the Commentariolus with commentary. Proceedings of the American Philosophical Society 117: 423-512.

33. King D (1990) Science in the service of religion: The case of Islam. Impact of Science on Society 159: 245-262.

34. Said MH (1991) Medieval Muslim Thinkers and Scientists. Renaissance Publishing House, Delhi, India.

35. Saliba G (1995) A History of Arabic Astronomy: Planetary Theories during the Golden Age of Islam. New York University Press, New York, USA.

36. King D (1999) Islamic Astronomy, In: Walker Ch (Eds.), Astronomy before the Telescope. British Museum Press, London, United Kingdom.

37. Heidarzadeh T (2005) Patronage, networks and migration: TurcoPersian scholarly exchanges in the 15th, 16th and 17th centuries. Archives Internationales d'Histoire des Sciences 55: 419-434.

38. Morgan HM (2007) Lost History: The Enduring Legacy of Muslim Scientists, Thinkers, and Artists. National Geographic Books, Washington DC, USA.

39. Schoy C (1921) Über eine arabische Methode, die geographische Breite aus der Höhe der Sonne im 1. Vertikal (Höhe ohne Azimut) zu bestimmen. Annalett der Hydrographie und Maritimen Meteorologie 49: 124-133.

40. Leon HM (1931) A Great Muslim Astrologer. Islamic Culture 5: 434-441

41. Nasr HS (1968) Science and Civilization in Islam. Harvard University Press, Cambridge, England.

42. Lindberg DC (1992) The Beginnings of Western Science, The European Scientific Tradition in Philosophical, Religious, and Institutional Context, 600 B.C. to A.D. 1450. the University of Chicago Press, Chicago, USA.

43. King D, Samsó J, Goldstein R (2001) Astronomical handbooks and tables from the Islamic world (750-1900). Suhayl 2: 12-105.

44. Korzhumbayeva A (2012) Muslim Astronomers in the Islamic Golden Age, Archive for the History of Science Category, ELECTRUM Magazine.

45. Dunlop DM (1943) Muhammad bin Mūsā al Khwārizmī. The Journal of the Royal Asiatic Society of Great Britain and Ireland 2: 248-250.
46. Arndt A (1983) Al-Khwarizmi, The Mathematics Teacher 76(9): 668670 .

47. Saliba G (1998) Science and medicine. Iranian Studies 31(3/4): 681-690.

48. Hogendijk JP (1998) al-Khwarizmi. Pythagoras 38(2): 4-5.

49. Brentjes S (2007) Khwārizmī: Muḥammad ibn Mūsā al Khwārizmī, In: Hockey Th, et al. (Eds.). The Biographical Encyclopedia of Astronomers, Springer Reference, Springer, New York, USA

50. Oaks J (2009) Polynomials and equations in Arabic algebra. Archive for History of Exact Sciences 63(2): 169-203.

51. Solomon G (1926) The Origin of the Term "Algebra". The American Mathematical Monthly 33(9): 437-440.

52. Solomon G (1936) The Sources of al-Khowārizmìs Algebra. Osiris 1(1): 263-277.

53. Hughes B (1986) Gerard of Cremona's Translation of al-Khwārizmī's alJabr: A Critical Edition. Mediaeval Studies 48: 211-263.

54. Rozenfeld B (1990) Al-Khwarizmi's spherical trigonometry (Russian). Istor.-Mat. 32(33): 325-339.

55. Hogendijk JP (1991) Al-Khwārizmī's Table of the "Sine of the Hours" and the Underlying Sine Table. Historia Scientiarum 42: 1-12.

56. King D (2002) A Vetustissimus Arabic Text on the Quadrans Vetus. Journal for the History of Astronomy 33(112): 237-255.

57. Al-Hassani S (2007) 1001 Inventions: Muslim Heritage in Our World ( $2^{\text {nd }}$ edn.), Foundation for Science Technology and Civilization, United Kingdom.

58. El-Baz F (1973) Al-Khwarizmi: A New-Found Basin on the Lunar Far Side, Science, New Series. American Association for the Advancement of Science 180(4091): 1173-1176.

59. Hugh Th (1996) Early Astronomy. Springer Science \& Business Media Berlin, Germany.

60. Sesiano J (2000) Islamic mathematics, In: Selin H, D’Ambrosio U (Eds.) Mathematics across Cultures: The History of Non-western Mathematics. Springer Science \&Business Media, Berlin, Germany.

61. Nallino CA (1960) Al-Battānī, In: Encyclopaedia of Islam. (2 ${ }^{\text {nd }}$ edn.), E] Brill, Leiden, Germany.

62. Schlager N, Lauer J ( 2001) Science and Its Times: 700-1449. Gale Group Michigan, USA.

63. Griffin R (2006) Education in the Muslim World: Different perspectives. Symposium Books Ltd., Oxford, United Kingdom.

64. Van Benno D (2007) Battānī: Abū 'Abd Allāh Muhammad ibn Jābir ibn Sinān al-Battānī al-Ḥarrānī al-Șābi', In: Hockey Th, et al.(Eds.). The Biographical Encyclopedia of Astronomers, Springer, New York, USA

65. Nallino CA (2012) al-Battānī, In: Bearman P, Bianquis Th, Bosworth CE, van Donzel E, Heinrichs WP, Encyclopaedia of Islam. (2 ${ }^{\text {nd }}$ edn.), EJ Brill, Leiden, Netherlands.

66. Angelo JA (2014) Encyclopedia of Space and Astronomy. Infobase Publishing, New York, USA

67. Steinschneider M (1864) Ueber die Mondstationen (Naxatra), und das Buch Arcandam, Zeitschrift der Deutschen Morgenländischen Gesellschaft. Harrassowitz Verlag Press, Germany, 18: 118-201.

68. Steinschneider M (1871) Zur Geschichte der Uebersetzungen aus dem Indischen ins Arabische und ihres Einflusses auf die arabische Literatur; insbesondere über die Mondstationen (Naxatra) und darauf bezügliche Loosbücher, Zeitschrift der Deutschen Morgenländischen Gesellschaft. Harrassowitz Verlag Press, Germany 25: 378-428.

69. Suter H (1892) Das Mathematiker-Verzeichniss im Fihrist des Ibn Ab Ja'kûb an-Nadîm: Zum ersten Mal vollständig ins Deutsche überstetzt 
und mit Anmerkungen versehen Abhandlungen zur Geschichte der Mathematik 6(37): 1-87.

70. Suter H (1900) Die Mathematiker und Astronomen der Araber und ihre Werke, Abhandlungen zur Geschichte der mathematischen Wissenschaften mit Einschlub ihrer Anwendungen. 10(45): 62-65.

71. Suter H (1902) Nachträge und Berichtigungen zu Die Mathematiker und Astronomen der Araber und ihre Werke. Abhandlungen zur Geschichte der mathematischen Wissenschaften mit Einschluss ihrer Anwendungen 14: 55-185.

72. Suter H (1913) Abd al-Raḥmān bin 'Umar al-Ṣūfí, The Encyclopaedia of Islam. EJ Brill, Leiden, Netherlands.

73. Brockelmann C (1937) Geschichte der arabischen Literatur: Erster Supplementband. EJ Brill, Leiden, Netherlands.

74. Brockelmann C (1943) Geschichte der arabischen Literatur: Zweite den Supplementbänden angepasste Auflage. EJ Brill, Leiden, Netherlands.

75. Storey Ch (1958) Persian Literature: A Bio-Bibliographical Survey. Luzac \& Co, Ltd, London, United Kingdom 2(1).

76. Sayili A (1960) The Observatory in Islam and its Place in the General History of the Observatory. Publications of the Turkish Historical Society, Ankara, Turkey 7 (38).

77. Stern SM (1960) Abd al-Raḥmān bin 'Umar al-Ṣūfī, In: The Encyclopaedia of Islam. New Edition, Vol I, EJ Brill, Leiden, Netherlands.

78. Dodge Bc (1970) The Fihrist of al-Nadìm: A Tenth-Century Survey of Muslim Culture. Columbia University Press, New York, USA.

79. Sezgin F (1974) Geschichte des arabischen Schrifttums. Mathematik bis ca. 430 H, EJ Brill, Leiden, Netherlands.

80. Suter H (1986) Beiträge zur Geschichte der Mathematik und Astronomie im Islam. Institut für Geschichte der arabisch islamischen Wissenschaften, Frankfurt, Germany.

81. Kunitzsch P (1976) al-Sūfī, In: Gillespie C (ed.), Dictionary of Scientific Biography, Charles Scribner's Sons, New York.

82. Sezgin F (1978) Geschichte des arabischen Schrifttums. Astronomie bis ca. 430 H, EJ Brill, Leiden, Netherlands.

83. Sezgin F (1979) Geschichte des arabischen Schrifttums, Astrologie, Meteorologie und. Verwandtes bis ca. 430 H, EJ Brill, Leiden, Netherlands.

84. Kunitzsch P (1982) Abd-al-Raḥmān bin 'Omar Șūfī, In: Encyclopædia Iranica. Routledge \& Kegan Paul, London, United Kingdom.

85. Matvievskaia GP (1983) Abd ar-Rahman as-Sufi i ego rol' v istorii astronomii ('Abd al-Raḥmān al-Ṣūfì and his Role in the History of Astronomy). Istoriko-Astronomicheskie Issledovaniia 16: 92-138.

86. Rosenfeld B, İhsanoğlu E (2003) Mathematicians, Astronomers, and other Scholars of Islamic Civilization and their Works $\left(7^{\text {th }}-19^{\text {th }}\right.$ c.). Research Centre for Islamic History, Art and Culture $=$ Series of Studies and Sources on History of Science, Istanbul, Turkey.

87. Rosenfeld B (2004) A Supplement to Mathematicians, Astronomers, and other Scholars of Islamic Civilisation and their Works (7th-19th c.) Suhayl: International Journal for the History of the Exact and Natural Sciences in Islamic Civilization 4: 87-139.

88. Kunitzsch P (2007) Sūfì: Abū al-Husayn 'Abd-al-Rahmān ibn 'Umar al-Șūfī, In: Hockey Th (Edn.), The Biographical Encyclopedia of Astronomers, Springer, New York, USA.

89. Kunitzsch P (2008) Abd-al-Raḥmān al-Ṣūfĩ. The Encyclopaedia of Islam, EJ Brill, Leiden, Netherlands.

90. Hafez I (2010) 'Abd al-Raḥmān al-Ṣūfi and His Book of the Fixed Stars: A Journey of Re-Discovery. James Cook University, Australia.

91. Helaine S (2008) Encyclopaedia of the History of Science, Technology, and Medicine in Non-Western Cultures. Springer, New York, USA.
92. Kunitzsch P (2014) Șūfĩ: Abū al-Ḥusayn 'Abd-al-Raḥmān ibn 'Umar alȘūfï, In: Hockey Th, (ed.),The Biographical Encyclopedia of Astronomers: $2^{\text {nd }}$ Edition, Springer Press, New York, USA.

93. Van Gent RH (2014) Sufi, Abd al-Rahman, In: Kalin I, Ayduz S, Dali C, (Eds.), The Oxford Encyclopedia of Philosophy, Science and Technology in Islam. Oxford University Press, Oxford, United Kingdom.

94. King D (1970) Ibn Yunus. The Dictionary of Scientific Biography, New York, USA.

95. North J (1994) The Fontana History of Astronomy and Cosmology. Fontana Press, London, United kingdom.

96. King D (2007) Ibn Yūnus: Abū al-Hasan Alī ibn Abd al-Rahmān ibn Aḥmad ibn Yūnus al-Ṣadafī, In: Hockey Th, et al. (Eds.).The Biographical Encyclopedia of Astronomers, Springer, New York, USA.

97. King D (1978) Islamic Math and Science. Journal for the History of Astronomy 9: 212-219.

98. Hall BS (1978) The scholastic pendulum. Annals of Science, Taylor \& Francis, United Kingdom 35(5): 441- 462.

99. King D (1979) Ibn Yunus and the pendulum: A history of errors. Archives Internationales d'Histoire des Sciences 29(104): 35-52.

100. Eickelman DF, Piscatori J (1990) Muslim Travellers: Pilgrimage, Migration, and the Religious Imagination. University of California Press, USA.

101. Swerdlow MN (1993) Montucla's Legacy: The History of the Exact Sciences. Journal of the History of Ideas, 54(2): 299-328.

102. Berggren J L (2003) Episodes in the Mathematics of Medieval Islam. Springer Press, New York, USA.

103. Bosworth CE (1968) The Political and Dynastic History of the Iranian World (A.D. 1000-1217)In: Boyle JA(ed). The Cambridge History of Iran, The Saljuq and Mongol Periods, Cambridge University Press, Cambridge, England.

104. Kennedy ES(1975) The Exact Sciences In: FryeRN\&FisherWB(Eds)The Cambridge History of Iran: The period from the Arab invasion to the Saljuqs. Cambridge University Press, Cambridge, England.

105. Rahman HU (1990) A Chronology of Islamic History:570-1000 CE.Mansell Publishing, 24(1): 94-96.

106. Samian AL (1997) Al-Biruniin: Selin H (Ed)Encyclopedia of the History of Science Technology and Medicine in Non-Western Cultures. Springer Science \& Business Media, New York, USA.

107. Waardenburg J (1999) Muslim Perceptions of Other Religions: A Historical Survey. Oxford University Press, United Kingdom.

108. KhanMA(2001)Al-Biruni's Discovery of India: An Interpretative Study. Academic Books,USA, 973: 1048.

109. Wilczynski JZ (1959)On the Presumed Darwinism of Alberuni Eight Hundred Years before Darwin. Isis 50(4): 459-466.

110. Douglas AV(1973) Al-Biruni Persian Scholar 973-1048. Journal of the Royal Astronomical Society of Canada 67: 209-211.

111. Kujundzić E, Masić I(1999) Al-Biruni-a universal scientist. Journal of Medical Archives 53(2): 117-120

112. Al-Biruni R (2004) The Book of Instruction in The Elements of The Art of Astrology. Translated by Wright, RKessinger Publishing, USA.

113. Stephenson FR(2009)Historical Eclipses and Earth's Rotation. Cambridge University Press, Cambridge, England.

114. Samian AL (2011) Reason and Spirit in Al-Biruni's Philosophy of Mathematics, In: Tymieniecka AT (Ed.) Reason Spirit and the Sacral in the New EnlightenmentIslamic Philosophy and Occidental Phenomenology in Dialogue. Springer, Netherlands. 
115. Browne E (1899) Yet More Light on 'Umar-i-Khayyām. Journal of the Royal Asiatic Society of Great Britain and Ireland 1(1): 409-420.

116. Ross E (1927) Omar Khayyam. Bulletin of the School of Oriental Studies University of London 4 (3): 433-439.

117. Smith DE (1935) EuclidOmar Khayyâm, and Saccheri. Scripta Mathematica 3(1): 5-10.

118. Deborah AK, David JM (2015) A Geometric Solution of a Cubic by Omar Khayyam in Which Colored Diagrams Are Used Instead of Letters for the Greater Ease of Learners. The American Mathematical Monthly 123(2): 149-160.

119. StruikD(1958)Omar Khayyam.Mathematician. The Mathematics Teacher 51(4): 280-285.

120. Kennedy E (1966)Omar Khayyam. The Mathematics Teacher 59(2): 140-142.

121. Rolwing R, Levine M(1969)The Parallel Postulate. The Mathematics Teacher 62(8): 665-669.

122. Farrell Ch (1998) The ninth-century renaissance in astronomy. The Physics Teacher 134 (5): 268-272.

123. AlexanderJ(2000) Calendrical II: Date Equations from the Reign of Augustus. ZeitschriftfürPapyrologie und Epigraphik 129: 159-166.

124. Blackburn B, HolfordStrevens L (2003) The Oxford Companion to the Year. Oxford University Press, United Kingdom.

125. Bennett CJ (2004) The Imperial Nundinal Cycle. ZeitschriftfürPapyrologie und Epigraphik 147: 175-179.

126. SternS(2012) Calendars in Antiquity: Empires States and Societies. Oxford University Press, United Kingdom.

127. Richards EG (2013) Urban In: Sean E, Seidelmann P (Eds.) Explanatory Supplement to the Astronomical Almanac (3rd Ed.). Calif University Science Books, California, USA

128. Kettani M (1984) Science and Technology in Islam in: Sardar Z (Ed.) The Underlying Value System the Touch of Midas; Science Values and Environment in Islam and the West. Manchester University Press, Manchester.

129. Gingerich 0 (1986) Islamic astronomy Scientific American. Scientific American Inc 254 (4): 74-83.

130. Morelon R(1996) Eastern Arabic Astronomy In: Rashed R (Ed.).Encyclopaedia of the History of Arabic Science, Routledge Press, London.

131. Rosenthal F (1950) Al-Asturlâbî and as-Samaw'al on Scientific Progress. Osiris 19: 555-564.

132. King D (1986) A Survey of the Scientific Manuscripts in the Egyptian National Library. Catalogs American Research Center in Egypt, AUC Press, Egypt.

133. Goldstein B (1986) The Making of Astronomy in Early Islam Nuncius: Annali di Storia dellaScienza, Italy p. 79-92.

134. King D (1990) Science in the Service of Religion: The Case of Islam impact of science on society (UNESCO). 159: 245-262.

135. Saliba G (1992) The Role of the Astrologer in Medieval Islamic Society. Bulletin d'étudesorientales, Institute Français de Damas, 144: 45-67.

136. Goldstein B (2001) Astronomy and the Jewish Community in Early Islam. Aleph 1(1): 17-57.

137. King D(1991) Medieval Astronomical Instruments: A Catalogue in Preparation. Bulletin of the Scientific Instrument Society 31: 3-7.

138. Lorch R, King D (1992)Qibla ChartsQibla Maps, and Related Instruments In: Harley J \& Woodward D (Eds.) The History of Cartography 2(1): Cartography in the Traditional Islamic and South Asian Societies. The University of Chicago Press, Chicago, USA.
139. King D (1994) Astronomical Instruments between East and West In: Kühnel H(Ed.) Kommunikationzwischen Orient und OkzidentSitzungsberichte der Österreichischen Akademie der Wissenschaften Phil.-Hist. Klasse, Veröffentlichungen des InstitutsfürRealienkunde des Mittelalters und der frühenNeuzeit, Österreichische Akademie der Wissenschaften, Austria pp.143-198.

140. King $D(1998) L e s$ instruments scientifiques en terred'IslamIn:MakariouS(Ed.).L'apparence des cieux-Astronomie et astrologie en terred'Islam, Éditions de la Réunion des muséesnationaux,Paris, France.

141. King D(1981) Early Islamic astronomy. Journal for the History of Astronomy12: 55-59.

142. King D (1982) On the astronomical orientation of the Kaaba. Journal for the History of Astronomy13: 102-109.

143. King D (1982) Astronomical alignments in medieval Islamic religious architecture. Annals of the New York Academy of Sciences 385: 303312.

144. King D (1982) Faces of the KaabaThe Sciences. The New York Academy of Sciences 22(5): 16-20.

145. King D (1996) Astronomy in Islamic society: Qibla, Gnomonics and Timekeeping.Rashed R, MorelonR(Eds.), Encyclopaedia of the History of Arabic ScienceRoutledge Press, New York, USA3(1).

146. King D (1997) Astronomie et sociétémusulmane: qibla, gnomonique, mîqât, In.RashedR, MorelonR, (Eds.), Histoire des sciences arabesÉditions du Seuil Paris 3(1).

147. Nallino C (1921) Sun Moon and Stars (Muhammadan)In: Hastings J (Ed.), Encyclopaedia of Religion and Ethics, TTClark Press, Scotland 12(12).

148. Goldstein B (1986) The Making of Astronomy in Early IslamNuncius: Annali di Storia dellaScienz, Italy 1(2): 79-92.

149. Savage Smith E (1988) Gleanings from an Arabists Workshop: Current Trends in the Study of Medieval Islamic Science and MedicineIsis 79(297):246-266.

150. Schmidl PG(1997) Two Early Arabic Sources On The Magnetic Compass. Journal of Arabic and Islamic Studies 1: 81-132.

151. Friedmann Y (2003) Tolerance and coercion in Islam: Interfaith relations in the Muslim tradition. Cambridge University Press, England.

152. King D (2005) The Sacred Geography of Islam In. KoetsierT, BergmansL (Eds.), Mathematics and the Divine: A Historical Study $1^{\text {st }}($ Eds.), Elsevier Science, Netherlands.

153. Hockey Th (2007) The Biographical Encyclopedia of Astronomers. Springer, NewYork, USA.

154. Moussa A(2011) Mathematical Methods in Abū al-Wafă’s Almagest and the Qibla Determinations. Arabic Sciences and Philosophy 21(1): $1-56$.

155. Kennedy S (1964) Al-Khwârizmîn the Jewish Calendar. Scripta Mathematica 27: 55-59.

156. King D (1975)Al-Khalîlî's Qibla Table. Journal of Near Eastern Studies 34: 81-122.

157. Morelon R (1981) Fragment arabe du premier livre du Phaseis de Ptolémée. Journal for the History of Arabic Science 5: 3-22.

158. Hawkins G, King D (1982) On the astronomical orientation of the Kaaba. Journal for the History of Astronomy 13: 102-109.

159. King D (1983) Al-Bazdawî on the Qibla in early Islamic Transoxania. Journal for the History of Arabic Science 7: 3-38.

160. King D (1995) The orientation of medieval Islamic religious architecture and cities. Journal for the History of Astronomy 26(3): 253-274. 
161. Folkerts M (1997) Die ältestelateinischeSchriftüber das indischeRechnennach al-Hwârizmî. Beck PressMunich.

162. Kunitzsch P(1998) The Enterprise of Science in Islam: New Perspectives In: the proceedings of a conference; New perspectives on science in medieval Islam. Dibner Institute, England p. 6-8.

163. King D (1999) Aspects of Fatimid astronomy: From hard-core mathematical astronomy to architectural orientations in Cairo BarrucandM (Ed.), Fatimid Egypt its art and its history-Proceedings of the symposium organized in Paris, Presses de lUniversité de ParisSorbonne Paris p. 497-517.

164. Langermann Y (1985) The Book of Bodies and Distances of Habash alHâsib. Centaurus 28: 108-128.

165. Mercier P (1992) Geodesy HarleyJ, Woodward D (eds.), The History of Cartography. Cartography in the Traditional Islamic and South Asian Societies. University of Chicago Press, USA 2(1).

166. King D (2000) Too Many Cooks A Newly Rediscovered Account of the First Islamic Geodetic Measurements Suhayl. Journal for the History of the Exact and Natural Sciences in Islamic Civilization, Spain 1: 71-99.

167. King D (1975) Astronomical Timekeeping (ilm al-mîqât) in medieval Islam. Actes du XXIX Congrès International des OrientalistesL Asiathèque2: 86-90.

168. King D (1998) Mamluk astronomy and the institution of the muwaqqit. PhillippTh, HaarmannU(Eds.),The Mamluks in Egyptian Politics and Society, Cambridge University Press, England.

169. King D (1984) Architecture and astronomy: The Ventilators of Medieval Cairo and their Secrets. Journal of the American Oriental Society Studies in Islam and the Ancient Near East Dedicated to Franz Rosenthal 104(1): 97-133.

170. King D (1973) Ibn YunusVery Useful Tables for Reckoning Time by the Sun. Archive for History of Exact Sciences 10: 342-394

171. King D (1983) The Astronomy of the Mamluks. ISIS74(4): 531-555.

172. Fernini M (2009) Astronomy at the service of the Islamic society. Proceedings of the International Astronomical Union 5(S260): 514521.

173. Berggren L (2001) Sundials in Medieval Islamic Science and Civilization. The Journal of Compendium 8(2): 8-14.

174. Hogendijk JP (2001) The Contributions by AbūNașr Ibn Irāq, Al-ṣaghānĩ to The Theory of Seasonal Hour Lines on Astrolabes and Sundials. Zeitschriftfür Geschichte der Arabisch-Islamischen Wissenschaften $14: 1-30$

175. Al-Khwārizmī (1983) Construction of Hours on the Plane of Sundials Translated. Al-DabbaghJ, and Commentary by: al-DabbaghJ, RosenfeldBA, Muhammad ibn Musa al-KhwarizmiMoscow Russia pp.221-234.

176. Niri MA (2012)Astronomical Determinations for the Beginning Prayer Time of Isha'. Middle East Journal of Scientific Research 12(1): 101107.

177. Rosenfeld BA (2008) Sundials in Islam. SelinH(Ed.), Encyclopaedia of the History of ScienceTechnology and Medicine in Non-Western Cultures. Springer Press, Netherlands.

178. Crecelius D (1978) The Waqf of Muhammad Bey Abu al-Dhabab. Journal of the American Research Center in Egypt 25: 83-105.

179. Crecelius D(1979) The Waqf of Muhammad Bey Abu al-Dhabab. Journal of the American Research Center in Egypt 26: 125-146.

180. Ülkü B(1991)Façades in Ottoman Cairo. BiermanI, PreziosiD (Eds.), The Ottoman City and its Parts: Urban Structure and Social Order. AD Caratzas Press, New York, USA.

181. Rufus WC (1939) The Influence of Islamic Astronomy in Europe and the Far East. Popular Astronomy 47(5): 233-238.
182. Kennedy ES (1947) Al-Kashi's Plate of Conjunctions. Isis 38(1/2): 5659.

183. Kennedy ES (1950) A Fifteenth-Century Planetary Computer: AlKashi's "Tabaq al-Manateq" I, Motion of the Sun and Moon in Longitude. Isis 41(2): 180-183.

184. Kennedy ES (1951) An Islamic Computer for Planetary Latitudes. Journal of the American Oriental Society 71(1): 13-21.

185. Kennedy ES (1952) A Fifteenth-Century Planetary Computer: AlKashi's “Tabaq al-Maneteq” II: Longitudes, Distances, and Equations of the Planets. Isis 43(1): 42-50.

186. Wickens GM (1976) The Middle East as a world Centre of science and medicine, In: Savory RM (Ed.), Introduction to Islamic Civilization. Cambridge University Press, England.

187. Hill DR (1985) Al-Biruni's mechanical calendar. Annals of Science 42(2): 139-163.

188. Chaudhry R (1988) Muslim Festivals and Ceremonies. ( $2^{\text {nd }}$ edn.), Islam International Publications, UK.

189. Covington R (2007) Rediscovering Arabic science. Saudi Aramco World (May-June 2007 ed.) p. 2-16

190. El-Rouayheb K (2008) The Myth of the Triumph of Fanaticism in the Seventeenth-Century Ottoman Empire. Die Welt des Islams 48: 196221.

191. Waziri Y (2013) Al'eamarah walfalak, Ta'thier Al-Zawheer Al Falakia 'Al Mabani Hadarat Al Qadimah. 'Alam Al-Kotob Library Press, Egypt.

192. Kennedy ES (1962) Review: The Observatory in Islam and Its Place in the General History of the Observatory by Aydin Sayili. Isis 53(2): 237-239.

193. Van Dalen B (2002) Islamic Astronomical Tables in China The Sources for the Huihui li, In: Razaullah A (Ed.), History of Oriental Astronomy, Proceedings of the Joint Discussion-17 at the 23rd General Assembly of the International Astronomical Union, organized by the Commission 41 (History of Astronomy). Astrophysics and Space Science Library, Springer - Science + Business Media Press, Germany.

194. King D (2005) In Synchrony with the Heavens, Studies in Astronomical Timekeeping and Instrumentation in Medieval Islamic Civilization. Brill Academic Pub., Leiden, Netherlands.

195. Dallal A (2010) Islam, Science, and the Challenge of History. Yale University Press, USA.

196. Subtelny ME (2010) Tamerlane and his descendants: From paladins to patrons, In: Morgan DO, Reid A (Eds.). The New Cambridge History of Islam, The Eastern Islamic World, Eleventh to Eighteenth Centuries, Cambridge University Press, England.

197. Roberts V (1957) The Solar and Lunar Theory of Ibn ash-Shâtir. Isis 48(4): 428-432.

198. Sayili A (1958) Islam and the Rise of Seventeenth Century Science. Belleten 22: 253-268.

199. Kennedy S, Roberts V (1959) The Planetary Theory of Ibn ash-Shâtir. Isis 50: 227-235.

200. Hartner W (1973) Copernicus, the Man, the Work, and its History Proceedings of the American Philosophical Society 117: 416-417.

201. Sayili A (1980) Observatories In Islam: The International symposium on the Observatories in Islam Edited by Dizer M, Turkey p. 21-32.

202. Jamil R (2001) Tusi and Copernicus: The Earth's Motion in Context, Science in Context. Cambridge University Press, England 14(1/2): 145-163.

203. Ronald C (2002) The Sun in the Church: Cathedrals as Solar Observatories. The Catholic Historical Review 88(4): 779-782. 
204. Jamil R (2007) Ṭūsī: Abū Jacfar Muhammad ibn Muhammad ibn alHasan Nașīr al-Dīn al-Tūsī, In: Thomas Hockey Th , et al. (Eds.). The Biographical Encyclopedia of Astronomers, Springer Press, USA pp. 1153-1155

205. Morris J (2009) An Arab Machiavelli? Rhetoric, Philosophy and Politics in Ibn Khaldun's Critique of Sufism. Harvard Middle Eastern and Islamic Review 8: 242-291.

206. Mozaffari M, Zotti G (2012) Ghazan Khan's Astronomical Innovations at Maragha Observatory. The Journal of the American Oriental Society 132(3): 395-399.

207. Krisciunas K (1992) The Legacy of Ulugh Beg. Bulletin of the Association for the Advancement of Central Asian Research 5(1): 3-6.

208. Krisciunas K (1992) The Legacy of Ulugh Beg, In: Paksoy H (Ed.), Central Asian Monuments. Isis Press, Istanbul, Turkey.

209. Van Benno D (2007) Ulugh Beg: Muhammad Ṭaraghāy ibn Shāhrukh ibn Tīmūr. In: Hockey Th, et al. (Eds.). The Biographical Encyclopedia of Astronomers, Springer Press, USA.

210. Gautier A (2007) Le Recueil de Calendriers du Prince Timouride Ulug Beg(1394-1449). Le Bulletin. Institute National des Langues et Civilizations Orientales, Issue spécial Les calendriers pp. 117-123.

211. Hobden H (1999) Ulughbek and his Observatory in Samarkand., The Cosmic Elk Press, London, United Kingdom.

212. Djebbar A (2001) Une Histoire de la Science Arabe. Le Seuil Press, Paris, France.

213. Zaimeche S (2002) A cursory review of muslim observatories, Foundation for Science, Technology and Civilization. UK.

214. Fazlioglu I (2008) The Samarqand Mathematical-Astronomical School: A Basis for Ottoman Philosophy and Science. Journal for the History of Arabic Science 14: 3-68.

215. Michnik H (1923) Theorie einer Bifilar-Sonnenuhr. Astronomishe Nachrichten 217(5190): 81-90.

216. Cousins FW (1973) Sundials: The Art and Science of Gnomonics. Pica Press, New York, USA.

217. Sawyer F (1978) Bifilar Gnomonics. Journal of the British Astronomical association 88(4): 334-351.

218. Schaldach K (2004) The Arachne of the Amphiareion and the Origin of Gnomonics in Greece. Journal for the History of Astronomy 35(4): $435-445$

219. Vodolazhskaya L (2013) Analemmatic and Horizontal Sundials of the Bronze Age (Northern Black Sea Coast). Archaeoastronomy and Ancient Technologies 1(1): 68-88.

220. Kunitzsch P (1981) On the authenticity of the treatise on the composition and use of the astrolabe ascribed to Messahalla. Archives Internationales d'Histoire des Sciences Oxford 31(106): 42-62.

221. King D (1981) The Origin of the Astrolabe According to the Medieval Islamic Sources. Journal for the History of Arabic Science 5: 43-83.

222. Laird E (1997) Astrolabes and the Construction of Time in the Late Middle Ages. In: Carol P, Richard U (Eds.).Constructions of Time in the Late Middle Ages, Northwestern University Press, USA.

223. Janin L (1972) Le Cadran Solaire de la Mosquée Umayyade de Damas. Centaurus 16(4): 285-298.

224. Berggren JL (1985) The Origins of al-Biruni's "Method of the Zijes" in the Theory of Sundial. Centaurus 28: 1-16.

225. Savoie D (2004) L'heure des crépuscules sur les Cadrans Solaires Arabo-Islamiques. L'Astronomie 118: 426-432.

226. Morrison RG (2013) Islamic Astronomy, In: Lindberg DC, Shank MH (Eds.), The Cambridge History of Science, Medieval Science, Cambridge University Press, England.
227. Savoie D (2014) Sundials in Islam, In: Selin H, (edn.), Encyclopaedia of the History of Science, Technology, and Medicine in Non-Western Cultures. Springer, Netherlands.

228. Di Cesare M (2017) A Qibla Mušarriqa for the first al-Aqș à Mosque? A new Stratigraphic, Planimetric, and Chronological Reading of Hamilton's Excavation, and Some Considerations on the Introduction of the Concave Mihrāb. Ann Sez Orient 77: 66-96.

229. Saksono T, Fulazzaky M, Sari Z (2018) Geodetic Analysis of Disputed Accurate Qibla Direction., Journal of Applied Geodesy p. 1-10.

230. King D (1978) Three Sundials from Islamic Andalusia. Journal for the History of Arabic Science 2: 358-392.

231. King D (1991) Mizwala [sundial], The Encyclopaedia of Islam. New edition, fascs, EJBrill Press, 7: 117-118

232. King D (2002) Towards a History from Antiquity to the Renaissance of Sundials and Other Instruments for Reckoning Time by the Sun and Stars, In:Higton H(Eds) Sundials at Greenwich-A Catalogue of the Sundials, Nocturnals, and Horary Quadrants in the National Maritime Museum, Oxford University Press, United Kingdom.

233. King D (2004) Sundials. Annals of Science 61(3): 375-388.

234. SaleemM (2016) Gnomon Assessment for Geographic Coordinate Solar Horizontal \& Equatorial Coordinates, Time of Local Sunrise, Noon, Sunset, Direction of Qibla, Size of Earth \& Sun for Lahore Pakistan. Open Journal of Applied Science 6(2): 100-111.

235. King D (1978) Notes on the AstrolabistNastûlus/Bastûlus. Archives Internationalesd'Histoire des Sciences 28: 115-118.

236. King D(1979) On the Early History of the Universal Astrolabe in Islamic Astronomy and the Origin of the Term Shakkâzîya in Medieval Scientific Arabic. Journal for the History of Arabic Science 3: 244-257.

237. King D (1981) On the Origin of the Astrolabe According to the Medieval Arabic Sources. Journal for the History of Arabic Science 5: 43-83.

238. King D (1996) The Neglected Astrolabe, In: Folkerts, M(Eds) Mathematische Problemeim Mittelalter-Der lateinische und arabische Sprachbereich, Wolfenbütteler Mittelalter-Studien,Otto Harrassowitz, Wiesbaden 10: 45-55.

239. King D (1998) Astrolabe In: Bud R, Warner D (Eds) Instruments of Science: A Historical Encyclopedia, Garland Publishing, New York, USA.

240. Davidian ML, KennedyES (1961) Al-Qāyinī on the Duration of Dawn and Twilight. Journal of Near Eastern Studies 20(3): 145-153.

241. Rubin U (1987) Morning and evening prayers in early Islam. JSAI 10: 40-64.

242. Leibowitz HW, Owens DA (1991) Can Normal Outdoor Activities be carried out during Civil Twilight? Applied optics 30(24): 3501-3503.

243. Ahsan Z (2004) The Quran and Modern Theories of the Universe. Islamic Culture 78(4): 25-50.

244. Ahsan Z (2011) The Quran and Motions of the Sun and Moon. Islam and Science, New Age Islam. Com

245. Kennedy ES (1961) Al-Kashi's Treatise on Astronomical Observational Instruments, Journal of Near Eastern Studies 20(2): 98-108.

246. Ilyas M (1978) Astronomical Determination of Islamic Times. Journal of the Malaysian Branch of the Royal Asiatic Society pp. 46-53.

247. Sarwar G (2001) Islam Beliefs and Teachings. ( $3^{\text {rd }}$ edn.), The Muslim Educational Trust Press, London, UK.

248. Sarker A (2004) Understand My Muslim People, the basic practices of Islam. Barclay Press, USA

249. Bruin $F(1977)$ The first visibility of the lunar crescent. Vistas in Astronomy 21: 331-358.

250. Mc Nally D (1983) The Length of the Lunar Crescent. Quarterly. Journal of the Royal Astronomical Society 24(4): 417-418. 
251. Ilyas M (1994) Lunar Crescent Visibility Criterion and Islamic Calendar Quarterly Journal of the Royal Astronomical Society 35(4): 425-461.

252. Schaefer BE (1996) Lunar Crescent Visibility. Quarterly Journal of the Royal Astronomical Society, 37(4): 759-760.

253. Sultan A (2006) Best time for the visibility of the lunar crescent. The Observatory 126:115-118.

254. Ilias MF (2009) Astronomy at the service of the Islamic society. Proceedings of the International Astronomical Union 260: 514-521.

255. Razvi A (1985) The Observatory at Samarqand. (Marsade Ulugh Beg, $15^{\text {th }} \mathrm{C}$ ), Central Asia17: 97-150.

256. Krisciunas K (1992) The accuracy of the measurements in Ulugh Beg's star catalogue. Bulletin of the American Astronomical Society 24(4): 1166-1167

257. Krisciunas K (1993) Analysis of the errors in Ulugh Beg's star catalogue, Journal for the History of Astronomy 24: 269-280.

258. Qura'n ,Surah Yunus, Verse 5.

259. Ahsan Z (2012) The Qura'n and Laws of Planetary Motion, Revelation and Science 2(1): 43-50.

260. Morrison R (2013) Natural Theology and the Qur'an. Journal of Qur'anic Studies, Edinburgh University Press, Germany 15(1): 1-22.

261. Exton H (1992) A Fresh Analysis of Some Recent Data on Atmospheric Refraction Near the Horizon with Implications in Archaeoastronomy. Journal for the History of Astronomy 23(17): S57-S58.

262. Forsythe W, Edward JR, Randal SS, Robert MS, Hsin-iWu, etal. (1995) A model comparison for day length as a function of latitude and day of year. Journal of Ecological Modelling 80(1): 87-95.

263. Hugh Th (2001) Early Greek Solstices and Equinoxes. Journal for the History of Astronomy 32(2): 154-156.

264. Yallow BD, Hohenkerk CY, Bell SA (2013)Astronomical Phenomena. In: Urban SE, Seidelmann PK (eds) Explanatory supplement to the astronomical almanac ( $3^{\text {rd }}$ edn.), University Science Books, Mill Valley, California, USA

265. Hilton JL, McCarthy DD (2013) Precession, Nutation, Polar Motion, and Earth Rotation, In: Urban, SE,Seidelmann PK (Eds) Explanatory supplement to the astronomical almanac $\left(3^{\text {rd }}\right.$ edn.) University Science Books, Mill Valley, California, USA.

266. King D (1985) The Sacred Direction in Islam A Study of the Interaction of Religion and Science in the Middle Ages. Journal of Interdisciplinary Science Reviews 10(4): 315-328.

267. King D (1997) Two Iranian world maps for finding the direction and distance to Mecca. Imago Mundi. The International Journal for the History of Cartography 49(1): 62-82.

268. King D (1999) World-Maps for finding the direction and distance to Mecca: Innovation and tradition in Islamic science. Al-Furqan Islamic Heritage Foundation, EJ Brill, Netherlands.

269. King D (1978) Some Medieval Values of the Qibla at Cordova. Journal of History of Arabic Science 2: 370-387.

270. Olson RJM, Pasachoff JM (1992) The 1816 Solar Eclipse and the Comet 1811I in Linnell's Astronomical Album. Journal for the History of Astronomy 23(2): 120-133.

271. Holbrook JC, Baleisis A (2008) Naked-eye Astronomy for Cultural Astronomers. African Cultural Astronomy, Astrophysics and Space Science Proceedings pp. 53-55.

272. Imoti E (1979) The Ka'ba-i Zardušt, Orient. the Society for Near Eastern Studies in Japan 15: 65-69.

273. Hawting GR (1980) The Disappearance and Rediscovery of Zamzam and the 'Well of the Ka'ba. Bulletin of the School of Oriental and African Studies. University of London 43(1): 44-54.
274. Francis P (1994) The Hajj: The Muslim Pilgrimage to Mecca and the Holy Places. Princeton University Press, Princeton.

275. Schmidl P (1997) Two Early Arabic Sources On The Magnetic Compass. Journal of Arabic and Islamic Studies 1: 81-132.

276. Osman G (2005) Pre-Islamic Arab Converts to Christianity in Mecca and Medina: An Investigation into the Arabic Sources.The Muslim World 95(1): 67-80.

277. Watt W (2008) Makka-The pre-Islamic and early Islamic periods, In: P. Bearman P, et.al. (Eds.). Encyclopaedia of Islam, Brill, Netherlands.

278. Moussa A (2011) Mathematical Methods in Abū al-Wafā’s Almagest and the Qibla Determinations. Arabic Sciences and Philosophy, Cambridge University Press, England 21(1): 1-56.

279. Hartsock R (2014) The Temple of Jerusalem: Past, present, and future. Jewish Culture and History 16(2): 199-201.

280. Arberry A (1963) The Chester Beatty Library: A handlist of the Arabic Manuscripts, Hodges, Figgis \& CO LTD. Dublin, Ireland.

281. Razaullah A (2002) History of oriental astronomy: Proceedings of the joint discussion-17 at the 23rd General Assembly of the International Astronomical Union. organized by the Commission 41 (History of Astronomy), Springer Press, Japan pp. 135-143.

282. Stephen P (2013) Time in Early Modern Islam: Calendar, Ceremony, and Chronology in the Safavid, Mughal, and Ottoman Empires. Cambridge University Press, England.

283. Doris B (1993) Early Islamic Architecture in Cairo, Islamic Architecture in Cairo: An Introduction. the American University in Cairo Press, Egypt.

284. Creswell KAC (1979) Early Muslim Architecture. Oxford University Press and reprinted by Hacker Art Books, New York, USA.

285. Scanlon GT (1974) The Pits of Fustat: Problems of Chronology. The Journal of Egyptian Archaeology 60(1): 60-78.

286. Lévi-Provençal E (1960) Abū 'Ubayd al-Bakrī. Encyclopaedia of Islam, ( $2^{\text {nd }}$ edn.), Brill Press, Netherlands.

287. Vernet J (1970) Bakrī, Abū Ubayd Abdallāh Ibn Abd al-Azīz Ibn Muhammad, In: Gillispie Ch (Ed.), Dictionary of Scientific Biography, Charles Scribner's Sons Press, New York, USA.

288. Dachraoui F (1993) Al-Muizz li-Dīn Allāh, In: Bosworth CE, et al. (Eds.). The Encyclopaedia of Islam, Brill Press, Netherlands.

289. Creswell KAC (1969) Early Muslim Architecture. (2 $2^{\text {nd }}$ edn.), Oxford, United Kingdom.

290. Rabbat N (2003) Who was al-Maqrizi? A Biographical Sketch, Mamluk Studies Review. Middle East Documentation Center, the University of Chicago Press, USA 7(2): 1-19.

291. Diez E (1936) Mihrā b. Encyclopaedia of Islam, Brill Press, Netherlands, Europe.

292. Fehérvári G (1993) Mihrāb, Encyclopaedia of Islam. New edition, Brill Press, Netherlands, Europe.

293. Osman A (2014) Companions, In: Fitzpatrick C and Walker A Muhammad in History, Thought, and Culture: An Encyclopedia of the Prophet of God. ABC-CLIO, USA.

294. El Kadi G, Bonnamy A (2007) Architecture for the Dead: Cairo's Medieval Necropolis. The American University in Cairo Press, Egypt.

295. David S (2010) Understanding Cairo: The logic of a city out of control. The American University in Cairo Press, Egypt.

296. Abd al-Wahhab H (1940) Al-Asr al-Fatimi. Majallat al-Imara 2(5/6): 310-324.

297. Bloom J (1983) The Mosque of al-Hakim in Cairo, Muqarnas, Muqarnas. An Annual on Islamic Art and Architecture 1: 15-36. 
298. King JR (1984) The Restoration of the Al-Hākim Mosque in Cairo. Islamic Studies 23(4): 325-335.

299. Williams C, Doris B (1992) Islamic Architecture in Cairo: An Introduction. Journal of the American Research Center in Egypt 29: 226-229.

300. Barraclough S (1998) Al-Azhar: Between the Government and the Islamists. Middle East Journal 52(2): 236-249.

301. Rabbat N (1996) Al-Azhar Mosque: An Architectural Chronicle of Cairo's History. Muqarnas- An Annual on the Visual Culture of the Islamic World, Brill Press, Netherlands 13: 45-67.

302. King D (2018) Finding the Qibla by the sun and stars. A survey of the sources of Islamic sacred geography, Germany.

303. Dadoyan SB, Parsumean-Tatoyean S (1997) The Fatimid Armenians: Cultural and Political Interaction in the Near East. Brill, Netherlands.

304. Jarzombek M, Prakash V (2011) A Global History of Architecture. John Wiley\&Sons Press, USA.
305. Yeomans R (2006) The art and architecture of Islamic Cairo. Garnet \& Ithaca Press, New York, USA.

306. Hadda L (2008) Nella Tunisia medievale. Architettura e decorazione islamica (IX-XVI secolo), Liguori editore, Italy.

307. Bloom J (1999) Mamluk Art and Architectural History, Mamluk Studies Review, Middle East Documentation Center (MEDOC). The University of Chicago Press, USA pp. 31-57.

308. Rabbat N (2002) Perception of Architecture in Mamluk Sources, Mamluk Studies Review, Vol. VI, Middle East Documentation Center(MEDOC). The University of Chicago Press, USA pp. 155-176.

309. O'Kane B (2016) The Mosques of Egypt. The American University in Cairo Press, Egypt.

310. Williams C (2018) Islamic Monuments in Cairo: The Practical Guide ( $7^{\text {th }}$ edn.), The American University in Cairo Press, Egypt.

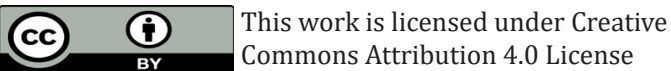

To Submit Your Article Click Here:

Submit Article

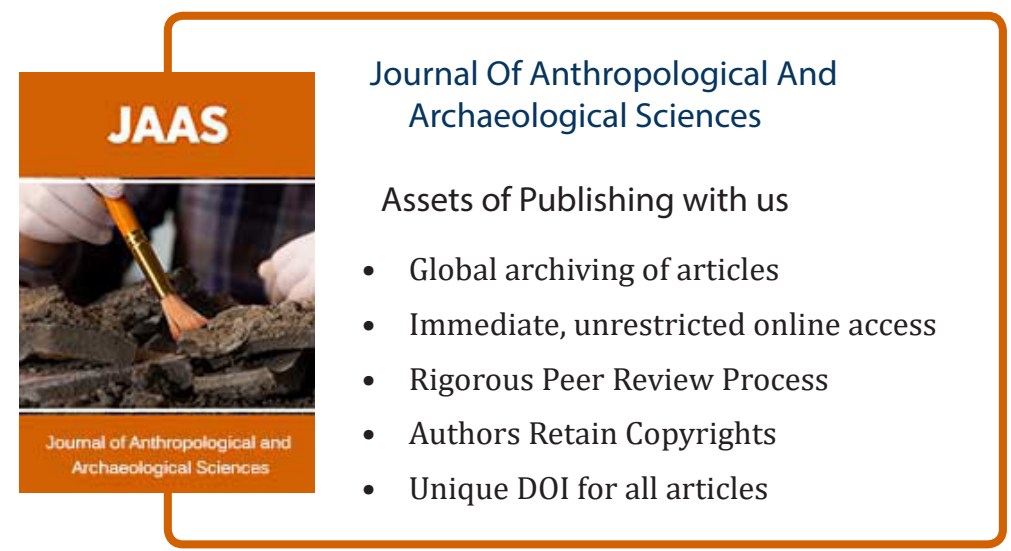

